\title{
Physicochemical characterization of ionic liquid
}

\section{binary mixtures containing 1-butyl-3-}

\section{methylimidazolium as the common cation ${ }^{¥}$}

Nicole S. M. Vieira, ${ }^{\dagger, l}$ Isabel Vázquez-Fernández, ${ }^{\ddagger, l}$ João M. M. Araújo, ${ }^{\dagger}$ Natalia V. Plechkova, ${ }^{\ddagger}$ Kenneth R. Seddon, ${ }^{\star,}$ Luís P. N. Rebelo, ${ }^{\dagger} * *$ Ana B. Pereiro ${ }^{\dagger} * *$

${ }^{\dagger}$ LAQV, REQUIMTE, Departamento de Química, Faculdade de Ciências e Tecnologia, Universidade Nova de Lisboa (FCT NOVA), 2829-516 Caparica, Portugal.

${ }^{\ddagger}$ QUILL Research Centre, School of Chemistry and Chemical Engineering, The Queen's University of Belfast, Belfast, BT9 5AG, UK

"Wellcome-Wolfson Institute for Experimental Medicine, School of Medicine, Dentistry and Biomedical Sciences, The Queen's University of Belfast, Belfast, BT9 5AG, UK

\section{AUTHOR INFORMATION}

\section{Corresponding Authors}

*anab@fct.unl.pt (A.B. Pereiro) ; luis.rebelo@fct.unl.pt (L.P.N. Rebelo)

${ }^{¥}$ In memory of Professor Kenneth R. Seddon, O.B.E.

"These authors have equally contributed to this work

${ }^{\S}$ Deceased author 


\section{ABSTRACT}

Mixing ionic liquids (as well as mixing an inorganic salt in an ionic liquid) constitutes an easy, elegant methodology to obtain new ionic materials. In this study, three ionic liquids (ILs) sharing a common cation were synthesized and mixed in nine different proportions giving rise to twentyseven binary mixtures. Specifically, 1-butyl-3-methylimidazolium nitrate, $\left[\mathrm{C}_{4} \mathrm{C}_{1} \operatorname{Im}\right]\left[\mathrm{NO}_{3}\right], 1$ butyl-3-methylimidazolium chloride, $\quad\left[\mathrm{C}_{4} \mathrm{C}_{1} \mathrm{Im}\right] \mathrm{Cl}$, and 1-butyl-3-methylimidazolium methanesulfonate, $\left[\mathrm{C}_{4} \mathrm{C}_{1} \mathrm{Im}\right]\left[\mathrm{CH}_{3} \mathrm{SO}_{3}\right]$, were synthetized and characterized. They all share 1-butyl3-methylimidazolium as the common, archetypal cation. None of them (or any of their binary mixtures $)$ is liquid at the room temperature $(T=298.15 \mathrm{~K})$ and two of them are only in the liquid state above temperatures of 343-353 K. Despite belonging to commonly used families of ILs, their handling and the study of their liquid properties (neat and mixtures) has become particularly difficult, mainly due to their tendency to solidify and their high viscosity (caused by hydrogenbonded networks). The main goal of this work is to evaluate the thermal, dynamic, and volumetric properties of these compounds and their mixtures, as well as the solid-liquid equilibria of their binary mixtures. Thermal properties, such as melting and glass transition temperatures were determined or calculated. Therefore, both density and viscosity have been measured, which were used for the calculation of the isobaric thermal expansion coefficient, molar volumes, excess molar volumes and viscosity deviations to linearity.

\section{KEYWORDS}

Ionic Liquids; Binary Mixtures; Solid-liquid Equilibria; Viscosity; Density; Excess Properties 


\section{INTRODUCTION}

Since their discovery in 1914 to date, the number of synthesized and studied ionic liquids (ILs) had increased dramatically in the most diverse fields of interest. ${ }^{1-3}$ Their first applications were associated with the design of electrolytes for batteries in the electrochemical industry, ${ }^{4-7}$ and in several engineering processes. ${ }^{3,8-11}$ However, more recently, and due to the increasing knowledge about the cytotoxic and ecotoxic behavior of these compounds, several efforts have been made to utilize ILs in the pharmaceutical and medical fields. ${ }^{12-14}$

The use of these compounds in these distinct applications is supported by their exceptional properties, such as the relatively low melting point, low flammability, negligible vapor pressure, high thermal and chemical stability, high ionic conductivity and high solvation ability. ${ }^{15-19}$ Furthermore, those properties make them a feasible alternative to traditional and less environmentally friendly solvents. ${ }^{15-17}$ These new opportunities are also supported by their tuneability, in which enormous combinations can be achieved matching different cations and anions. This tuneability allows to obtain the desirable compound with the most favorable characteristics for each specific application. ${ }^{17,20}$ Despite the almost unmeasurable number of available ILs, the "tailoring" possibilities markedly increase when ILs binary and ternary mixtures are considered. $^{21-23}$

Considering the behavior of an ideal homogeneous mixture, it is expected that its properties are the result of the composition of each pure compound. However, and obviously, the linear behavior is simply an oversimplified model. Each mixture is a unique system, which may not follow exactly the expected behavior. ${ }^{21,23,24}$ 
Our laboratories have already devoted attention to this type of mixtures, including work which has been considered pioneering in the field..$^{23-27}$ Their importance is well documented in two recent critical reviews. $^{21,22}$ For instance, the ideal behavior of some mixtures containing either the same imidazolium-based cations or the same anion $\left(\left[\mathrm{NTf}_{2}\right]^{-},\left[\mathrm{PF}_{6}\right]^{-}\right.$or $\left.\left[\mathrm{BF}_{4}\right]^{-}\right)$conjugated with different counterparts has been evaluated in terms of excess properties, exhibiting a linear behavior with very small excess molar volumes. ${ }^{23}$ In the case of protonic ammonium nitrate ILs binary mixtures, a close to ideal behavior was observed with small deviations on the excess molar volume. ${ }^{25}$ In another study where 1-butyl-3-methylimidazolium was the common cation in several binary mixtures, it was observed that while very small deviations in the molar volume were detected large deviations were observed for the viscosity. ${ }^{26}$ In contrast with the aforementioned mixtures, a marked non-linear behavior was observed in the ionic conductivity, density and viscosity of ILs and inorganic salts mixtures. ${ }^{27}$

In general, volumetric ideal behavior is observed in IL binary mixtures, which does not mean that IL mixtures are ideal as liquid-liquid phase separation may occur. ${ }^{23,28}$ This fact highlights that a proper characterization of the mixtures must be performed prior to general assumptions based only on the properties of pure compounds. With this mindset, this work provides useful insights into the thermal, dynamic and volumetric properties, as well as the phase behavior of binary mixtures which contain a common, 1-butyl-3-methylimidazolium $\left(\left[\mathrm{C}_{4} \mathrm{C}_{1} \mathrm{Im}\right]^{+}\right)$cation, conjugated with either nitrate $\left(\left[\mathrm{NO}_{3}\right]^{-}\right)$, chloride $\left(\mathrm{Cl}^{-}\right)$or methanesulfonate $\left(\left[\mathrm{CH}_{3} \mathrm{SO}_{3}\right]^{-}\right)$anions $\left(\left[\mathrm{C}_{4} \mathrm{C}_{1} \mathrm{Im}\right]\left\{\left[\mathrm{NO}_{3}\right]_{(x)} \mathrm{Cl}_{(1-x)}\right\},\left[\mathrm{C}_{4} \mathrm{C}_{1} \mathrm{Im}\right]\left\{\left[\mathrm{NO}_{3}\right]_{(x)}\left[\mathrm{CH}_{3} \mathrm{SO}_{3}\right]_{(1-x)}\right\}\right.$ and $\left.\left[\mathrm{C}_{4} \mathrm{C}_{1} \mathrm{Im}\right]\left\{\left[\mathrm{CH}_{3} \mathrm{SO}_{3}\right]_{(x)} \mathrm{Cl}_{(1-x)}\right\}\right)$. The pure ionic liquids were selected based on their melting points lower than $373.15 \mathrm{~K}$ (true ionic liquids according to their arbitrary definition) and in the structurally simplest nature of the anions that are also hydrogen-bond formers. Furthermore, new interactions in the binary mixtures in the 
environment of the cation with the moderate hydrogen bonding ability and three strongly hydrogen-bonding anions can be established. The overall hydrogen-bonding ability of these aprotic ionic liquids is much weaker than that presented in our previous work ${ }^{25}$ where several binary mixtures of protonic alkylammonium nitrate ionic liquids have been studied. The data obtained in these experiments take an essential step regarding this new concept of mixing ILs to achieve different and more suitable properties compared to the pure compounds for various applications.

\section{EXPERIMENTAL SECTION}

2.1. Ionic Liquids Synthesis and Characterization. In terms of green chemistry, one of the issues with the use of ILs is their synthesis, which often generates halide salts or hydrogen chloride and large volumes of waste solvents. The remaining metal halide and moisture impurities are known to cause changes in their properties. ${ }^{29}$ In order to avoid this situation, several halide free synthetic methods have been considered in this work.

For the synthesis of 1-butyl-3-methylimidazolium nitrate $\left(\left[\mathrm{C}_{4} \mathrm{C}_{1} \mathrm{Im}\right]\left[\mathrm{NO}_{3}\right]\right)$, a procedure of synthesis developed by Ferguson et al. ${ }^{30}$ was applied, eliminating the use of halide ions and reducing significantly the need of organic solvents. In this process an aqueous solution of 1-butyl3-methylimidazolium hydrogen sulfate $(0.135 \mathrm{~mol} ; \geq 95 \%$ mass fraction purity, Sigma Aldrich, St. Louis, USA) was prepared, and mixed with an aqueous solution of strontium hydroxide octahydrate $(0.156 \mathrm{~mol} ; 95 \%$ mass fraction purity, Sigma Aldrich, St. Louis, USA). The final reaction mixture was stirred and cooled during 20 hours at $T=277.15 \mathrm{~K}$. The remaining precipitate was removed via filtration with silica gel, washed with water, and then discarded. A very dilute 
solution of $\left[\mathrm{C}_{4} \mathrm{C}_{1} \mathrm{Im}\right][\mathrm{OH}]$ was neutralized with nitric acid $(65 \%$ mass fraction purity, Microchem system, Westborough, USA) to $\mathrm{pH}=7$. The excess of water was removed under vacuum using a freeze-drier during 6 days. The final product, 1-butyl-3-methylimidazolium nitrate, obtained as a solid, was further characterized.

The synthesis of 1-butyl-3-methylimidazolium methanesulfonate $\left(\left[\mathrm{C}_{4} \mathrm{C}_{1} \mathrm{Im}\right]\left[\mathrm{CH}_{3} \mathrm{SO}_{3}\right]\right)$ was performed in two steps. Firstly, butyl methanesulfonate was prepared by dissolving butanol (1.078 mol; 99\% mass fraction purity, Alfa Aesar, Massachusetts, USA) and trimethylamine (1.226 mol; $45 \%$ mass fraction purity, Fluka, Munich, Germany) in toluene $\left(800 \mathrm{~cm}^{3}\right)$. Then, methanesulfonyl chloride (0.98 mol; $\geq 99 \%$ mass fraction purity, Fluka, Munich, Germany) was also dissolved in toluene, added dropwise to the previous mixture and cooled off in an ice bath to maintain the exothermic reaction temperature bellow $T=277.15 \mathrm{~K}$. During 48 hours, the mixture was stirred at room temperature and precipitated triethylammonium chloride was removed by filtration. Then, toluene was removed from the filtrate in vacuo at $T=313.15 \mathrm{~K}$. The remaining product was distilled at $T=343.15 \mathrm{~K}, 0.005 \mathrm{kPa}$ pressure for 6-8 hours in a Büchi B-590 Kugelrohr apparatus originating a liquid distillate. This step was performed several times to assure the full toluene elimination. This intermediate product, butyl methanesulfonate was checked by NMR spectroscopy.

For the synthesis of 1-butyl-3-methylimidazolium methanesulfonate, 1-methylimidazole (0.32mol; $99 \%$ mass fraction purity, Sigma Aldrich, St. Louis, USA) was added to butyl methanesulfonate $(0.32 \mathrm{~mol})$ in an ethyl ethanoate solution ( $>99.5 \%$ mass fraction purity, Riedelde-Haën, Bucharest, Romania). The reaction product was separated by decantation and washed three times with toluene. Then, the product was dried in high vacuo at $T=348.15 \mathrm{~K}$ during 3 days. The final product, 1-butyl-3-methylimidazolium methanesulfonate was further characterized. 
Finally, for the synthesis of 1-butyl-3-methylimidazolium chloride $\left(\left[\mathrm{C}_{4} \mathrm{C}_{1} \mathrm{Im}\right] \mathrm{Cl}\right)$, 1chlorobutane (2.53 mol; $99.5 \%$ mass fraction purity, Sigma Aldrich, St. Louis, USA), was added to 1 -methylimidazole (2.32 mol; $99 \%$ mass fraction purity, Sigma Aldrich, St. Louis, USA). The reaction mixture was heated with stirring under dry reflux at $T=343.15 \mathrm{~K}$ during 6 days. The final product, 1-butyl-3-methylimidazolium chloride was obtained as a solid after the reaction was cooled to room temperature and was further characterized.

The synthesis procedures are shown in Scheme 1, and the purification and characterization methods were identified in Table 1 . The isolated products were characterized by ${ }^{1} \mathrm{H}$ (Figures $\mathrm{S} 1$ S3) and ${ }^{13} \mathrm{C}$ NMR spectroscopy, elemental analysis and liquid secondary ion mass spectrometry (LSIMS). The ${ }^{1} \mathrm{H}$ and ${ }^{13} \mathrm{C}$ NMR spectra were recorded at room temperature using a Bruker Avance spectrometer (400 MHz) Bruker-Spectrospin 400. ${ }^{1} \mathrm{H}$ NMR and ${ }^{13} \mathrm{C}$ NMR spectra of the ILs were referenced with respect to tetramethylsilane. Elemental analysis $(\mathrm{CHN})$ was carried out by the Analytical Services and Environmental Projects Unit (ASEP) at the Queen's University of Belfast. The instrument used was the Perkin-Elmer Series II CHNS/O 2400 CHN Elemental Analyser, which provided analytical results within an uncertainty of 0.003 in wt of the theoretical values. LSIMS spectra were recorded using a Micromass Autospec X Series spectrometer with a $25 \mathrm{kV}$ voltage. The mass spectra of liquid samples were recorded neat; the mass spectra of solid samples were recorded in a 3-nitrobenzylalcohol matrix. The water content was determined by Karl Fischer (KF) titration in a Metrohm $831 \mathrm{KF}$ coulometer.

The characterization of $\left[\mathrm{C}_{4} \mathrm{C}_{1} \mathrm{Im}\right]\left[\mathrm{NO}_{3}\right]:{ }^{1} \mathrm{H}-\mathrm{NMR}\left(400 \mathrm{MHz}, \mathrm{CDCl}_{3}\right): \delta(\mathrm{ppm}) 0.94(\mathrm{t}, 3 \mathrm{H}$, $\left.\mathrm{CH}_{3}\right), 1.36\left(\mathrm{~m}, 2 \mathrm{H}, \mathrm{CH}_{2}\right), 1.88\left(\mathrm{~m}, 2 \mathrm{H}, \mathrm{NCH}_{2} \mathrm{CH}_{2}\right), 4.02\left(\mathrm{~s}, 3 \mathrm{H}, \mathrm{NCH}_{3}\right), 4.25\left(\mathrm{t}, 2 \mathrm{H}, \mathrm{NCH}_{2}\right), 7.49$ (s, 1H, ArH), $7.56(\mathrm{~s}, 1 \mathrm{H}, \mathrm{ArH}), 9.79(\mathrm{~s}, 1 \mathrm{H}, \mathrm{ArH}) ; \geq 97.5 \%$ mass fraction purity; ${ }^{13} \mathrm{C}-\mathrm{NMR}(75$ $\mathrm{MHz}, d_{1}$-trichloromethane): $\delta / \mathrm{ppm}=137.46(\mathrm{NCHN}), 125.05(\mathrm{NCH}), 122.80(\mathrm{NCH}), 49.76$ 
$\left(\mathrm{NCH}_{2} \mathrm{CH}_{3}\right), 35.18\left(\mathrm{NCH}_{3}\right), 31.81\left(\mathrm{CH}_{2} \mathrm{CH}_{2} \mathrm{CH}_{3}\right), 19.38\left(\mathrm{CH}_{2} \mathrm{CH}_{3}\right), 13.2\left(\mathrm{CH}_{2} \mathrm{CH}_{3}\right)$; Water content less than 400 ppm.

The characterization of $\left[\mathrm{C}_{4} \mathrm{C}_{1} \mathrm{Im}\right]\left[\mathrm{CH}_{3} \mathrm{SO}_{3}\right]:{ }^{1} \mathrm{H}-\mathrm{NMR}(400 \mathrm{MHz}, \mathrm{CDCl} 3) \delta(\mathrm{ppm}) 0.96(\mathrm{t}, 3 \mathrm{H}$, $\left.\mathrm{CH}_{3}\right), 1.38\left(\mathrm{~m}, 2 \mathrm{H}, \mathrm{CH}_{2}\right), 1.89\left(\mathrm{~m}, 2 \mathrm{H}, \mathrm{NCH}_{2} \mathrm{C}_{2} 2\right), 2.75\left(\mathrm{~s}, 3 \mathrm{H},\left(\mathrm{SO}_{3}\right) \mathrm{CH}_{3}\right), 4.06\left(\mathrm{~s}, 3 \mathrm{H}, \mathrm{NCH}_{3}\right)$, $4.29\left(\mathrm{t}, 2 \mathrm{H}, \mathrm{NCH}_{2}\right), 7.60(\mathrm{~s}, 1 \mathrm{H}, \mathrm{ArH}), 7.70(\mathrm{~s}, 1 \mathrm{H}, \mathrm{ArH}), 9.79(\mathrm{~s}, 1 \mathrm{H}, \mathrm{ArH}) ; \geq 98 \%$ mass fraction purity; ${ }^{13} \mathrm{C}-\mathrm{NMR}\left(75 \mathrm{MHz}, d_{1}\right.$-trichloromethane): $\delta / \mathrm{ppm}=137.88(\mathrm{NCHN}), 124.17(\mathrm{NCH})$; $122.56(\mathrm{NCH}) ; 49.80\left(\mathrm{NCH}_{2} \mathrm{CH}_{3}\right) ; 40.05\left(\mathrm{NCH}_{3}\right) ; 36.51\left(\mathrm{CH}_{3} \mathrm{~S}\right) ; 32.35\left(\mathrm{CH}_{2} \mathrm{CH}_{2} \mathrm{CH}_{3}\right) ; 19.63$ $\left(\mathrm{CH}_{2} \mathrm{CH}_{3}\right) ; 13.65\left(\mathrm{CH}_{2} \mathrm{CH}_{3}\right) ; \mathrm{CHN}$ analysis: \% calculated $\mathrm{C} 46.13 \%, \mathrm{H} 7.74 \%$ and $\mathrm{N} 11.96 \%$; observed: C 45.89\%, H 8.45\% and N 11.61\%; MS (ESI ${ }^{+}$) [m/z (rel. int. (\%)]: M+ 139 (100, $\left.\left[\mathrm{C}_{4} \mathrm{C}_{1} \mathrm{Im}\right]^{+}\right)$; Water content less than $450 \mathrm{ppm}$.

The characterization of $\left[\mathrm{C}_{4} \mathrm{C}_{1} \mathrm{Im}\right] \mathrm{Cl},{ }^{1} \mathrm{H}-\mathrm{NMR}\left(400 \mathrm{MHz}, \mathrm{CDCl}_{3}\right): \delta(\mathrm{ppm}) 0.96\left(\mathrm{t}, 3 \mathrm{H}, \mathrm{CH}_{3}\right), 1.39$ (m, 2H, $\left.\mathrm{CH}_{2}\right), 1.91\left(\mathrm{~m}, 2 \mathrm{H}, \mathrm{NCH}_{2} \mathrm{CH}_{2}\right), 4.14\left(\mathrm{~s}, 3 \mathrm{H}, \mathrm{NCH}_{3}\right), 4.35\left(\mathrm{t}, 2 \mathrm{H}, \mathrm{NCH}_{2}\right), 7.61(\mathrm{~s}, 1 \mathrm{H}, \mathrm{ArH})$, $7.78(\mathrm{~s}, 1 \mathrm{H}, \mathrm{ArH}), 10.56(\mathrm{~s}, 1 \mathrm{H}, \mathrm{ArH}) ; \geq 97 \%$ mass fraction purity; ${ }^{13} \mathrm{C}-\mathrm{NMR}\left(75 \mathrm{MHz}, d_{1-}\right.$ trichloromethane): $\delta / \mathrm{ppm}=137.20(\mathrm{NCHN}), 126.31(\mathrm{NCH}), 123.6(\mathrm{NCH}), 48.01\left(\mathrm{NCH}_{2} \mathrm{CH}_{3}\right)$, $34.12\left(\mathrm{NCH}_{3}\right), 32.81\left(\mathrm{CH}_{2} \mathrm{CH}_{2} \mathrm{CH}_{3}\right), 19.25\left(\mathrm{CH}_{2} \mathrm{CH}_{3}\right), 13.37\left(\mathrm{CH}_{2} \mathrm{CH}_{3}\right) ; \mathrm{CHN}$ analysis: \% calculated C 55.01\%, H 8.66\% and N 16.04\%; observed: C 54.89\%, H 8.73\% and N 15.97\%; MS $\left(\mathrm{ESI}^{+}\right)\left[\mathrm{m} / \mathrm{z}\right.$ (rel. int. (\%)]: $\mathrm{M}^{+} 139\left(100,\left[\mathrm{C}_{4} \mathrm{C}_{1} \mathrm{Im}\right]^{+}\right)$; Water content less than $600 \mathrm{ppm}$. 
Scheme 1. Synthesis Procedure Applied for Each IL Used in this Work

$\left[\mathrm{C}_{4} \mathrm{C}_{1} \mathrm{Im}\right]\left[\mathrm{NO}_{3}\right]$ (

Table 1. Designation, CAS Registry Number, Source, Purification Method, Purity, Analysis Method and Water Content of the Ionic Liquids Used in this Work. The Reagents Used in the Synthesis are Listed in Table S1 of SI

\begin{tabular}{|c|c|c|c|c|c|c|}
\hline component & CAS Reg. No. & source & $\begin{array}{l}\text { purification } \\
\text { method }\end{array}$ & $\begin{array}{l}\text { purity } \\
\text { (mass } \\
\text { fraction) }\end{array}$ & $\begin{array}{l}\text { analysis } \\
\text { method }\end{array}$ & $\begin{array}{l}\text { water } \\
\text { content } \\
(\mathrm{ppm})\end{array}$ \\
\hline $\begin{array}{l}\text { 1-butyl-3- } \\
\text { methylimidazolium } \\
\text { nitrate } \\
{\left[\mathrm{C}_{4} \mathrm{C}_{1} \mathrm{Im}\right]\left[\mathrm{NO}_{3}\right]}\end{array}$ & $179075-88-8$ & synthetized & $\begin{array}{c}\text { filtration, } \\
\text { neutralization } \\
\text { and vacuum } \\
\text { dried }\end{array}$ & $\geq 97.5 \%$ & $\begin{array}{c}{ }^{1} \mathrm{H} \text { and }{ }^{13} \mathrm{C} \\
\mathrm{NMR}^{a} ; \mathrm{KF} \\
\text { titration }^{b}\end{array}$ & 400 \\
\hline $\begin{array}{l}\text { 1-butyl-3- } \\
\text { methylimidazolium } \\
\text { methanesulfonate } \\
{\left[\mathrm{C}_{4} \mathrm{C}_{1} \mathrm{Im}\right]\left[\mathrm{CH}_{3} \mathrm{SO}_{3}\right]}\end{array}$ & $342789-81-5$ & synthetized & $\begin{array}{c}\text { filtration, } \\
\text { distillation and } \\
\text { vacuum dried }\end{array}$ & $\geq 98 \%$ & $\begin{array}{l}{ }^{1} \mathrm{H} \text { and }{ }^{13} \mathrm{C} \\
\mathrm{NMR}^{a} ; \mathrm{EA}^{c} ; \\
\mathrm{LSIMS}^{d} ; \mathrm{KF} \\
\text { titration }^{b}\end{array}$ & 450 \\
\hline $\begin{array}{l}\text { 1-butyl-3- } \\
\text { methylimidazolium } \\
\text { chloride } \\
{\left[\mathrm{C}_{4} \mathrm{C}_{1} \mathrm{Im}\right] \mathrm{Cl}}\end{array}$ & 79917-90-1 & synthetized & vacuum dried & $\geq 97 \%$ & $\begin{array}{l}{ }^{1} \mathrm{H} \text { and }{ }^{13} \mathrm{C} \\
\mathrm{NMR}^{a} ; \mathrm{EA}^{c} ; \\
\mathrm{LSIMS}^{d} ; \mathrm{KF} \\
\text { titration }\end{array}$ & 600 \\
\hline
\end{tabular}

\footnotetext{
${ }^{a}$ Nuclear Magnetic Resonance; ${ }^{b}$ Karl Fischer titration; ${ }^{c}$ Elemental analysis; ${ }^{d}$ Liquid secondary ion mass spectrometry
} 
2.2. Solid-liquid Phase Diagrams. A DSC Q2000 Differential Scanning Calorimeter (TA Instrument), with refrigerated cooling system, was used for the determination of the solid-liquid phase transitions and glass transition temperatures of the three pure ILs and their binary mixtures $\left(\left[\mathrm{C}_{4} \mathrm{C}_{1} \mathrm{Im}\right]\left[\mathrm{NO}_{3}\right]+\left[\mathrm{C}_{4} \mathrm{C}_{1} \mathrm{Im}\right]\left[\mathrm{CH}_{3} \mathrm{SO}_{3}\right],\left[\mathrm{C}_{4} \mathrm{C}_{1} \mathrm{Im}\right]\left[\mathrm{NO}_{3}\right]+\left[\mathrm{C}_{4} \mathrm{C}_{1} \mathrm{Im}\right] \mathrm{Cl}\right.$ and $\left[\mathrm{C}_{4} \mathrm{C}_{1} \mathrm{Im}\right]\left[\mathrm{CH}_{3} \mathrm{SO}_{3}\right]+$ $\left[\mathrm{C}_{4} \mathrm{C}_{1} \mathrm{Im}\right] \mathrm{Cl}$ at different concentrations. Dry dinitrogen gas was purged through the DSC cell with a flow rate of $c a .20 \mathrm{~cm}^{3} \mathrm{~min}^{-1}$. All the samples, due to their hygroscopic character, were prepared in a glove box. Thermophysical data were collected at atmospheric pressure accordingly to the method developed by Stolarska et al. ${ }^{31}$ All the samples were initially heated from room temperature, at a rate of $2.5 \mathrm{~K} \mathrm{~min}^{-1}$. At this temperature, they were held for an isotherm of 25 minutes, prior to two cycles of cooling and heating at rates of $2.5 \mathrm{~K} \mathrm{~min}^{-1}$ spaced by $10 \mathrm{~min}$ isothermal holding at the lower and upper end point temperatures. Solid-liquid phase transitions and glass transition temperatures were further analyzed using the TA Universal Analysis software. A dynamic visual method was also carried out to determine the solid-liquid transitions of the mixtures which correspond to the temperatures where the first liquid appears, and the last crystal disappears with a constant increment of temperature. The mixtures were prepared in glass vials equipped with stirring bars and using an analytical high-precision balance (0.01 mg resolution). The real molar composition of each compound is depicted in Tables S2-S4. The glass vials were thermostatized in either ethanol or silicon oil baths. Temperature was controlled using a four-wire platinum resistance thermometer coupled to a multimeter. The uncertainty of the SLE temperatures is estimated to be $3 \mathrm{~K}(\mathrm{u}(T)=3 \mathrm{~K})$.

2.3. Density and Viscosity. Measurements of density and viscosity of the pure ILs and their binary mixtures were performed in an automated SVM 3000 Anton Paar rotational Stabinger viscometer-densimeter at atmospheric pressure in the 293.15 - $363.15 \mathrm{~K}$ temperature range. A fast 
and effective thermostability was guaranteed using Peltier elements. The temperature uncertainty of the equipment is $0.02 \mathrm{~K}(\mathrm{u}(T)=0.02 \mathrm{~K})$. For each IL sample duplicates were measured and the presented result is the average value from these measurements with a maximum relative standard deviation (RSD) of $0.0002 \mathrm{~g} \cdot \mathrm{cm}^{-3}$ for the density and $0.01 \mathrm{mPa} \cdot \mathrm{s}$ for the viscosity. The uncertainty of the measurements, considering the purity and the sample handling, is estimated to be 0.001 $\mathrm{g} \cdot \mathrm{cm}^{-3}(\operatorname{ur}(\rho)=0.001)$ for the density and $0.02 \mathrm{mPa} \cdot \mathrm{s}(\operatorname{ur}(\eta)=0.02)$ for the viscosity.

\section{RESULTS AND DISCUSSION}

3.1. Thermal Properties of Pure Ionic Liquids. In the DSC temperature runs, the maximum of the endothermic peak of the melting transition obtained during the second heating cycle (at a heating rate of $2.5 \mathrm{~K} \mathrm{~min}^{-1}$ ) was considered. DSC curves of the pure compounds and different mixtures are depicted in Figures S4-S9 of Supporting Information (SI). Discrepancies between experimental and literature values are likely due to the different heating rates used, or to a different strategy of melting point determination (onset $v s$. peak), and to a different water content of the samples. All DSC runs were performed two times independently. The melting points of the pure ionic liquids are shown in Table 2, and an acceptable agreement in the transition temperatures with published data has been observed for the pure compounds $\left(\left[\mathrm{C}_{4} \mathrm{C}_{1} \mathrm{Im}\right]\left[\mathrm{NO}_{3}\right],\left[\mathrm{C}_{4} \mathrm{C}_{1} \mathrm{Im}\right]\left[\mathrm{CH}_{3} \mathrm{SO}_{3}\right]\right.$ and $\left.\left[\mathrm{C}_{4} \mathrm{C}_{1} \mathrm{Im}\right] \mathrm{Cl}\right) .{ }^{31-36}$ This table also presents the glass transition and the solid-phase transition temperatures determined in this work. For $\left[\mathrm{C}_{4} \mathrm{C}_{1} \mathrm{Im}\right]\left[\mathrm{NO}_{3}\right]$, a solid-solid transition at $T=279 \mathrm{~K}$ was also observed, which is in accordance with the values reported by Strechan et. al. ${ }^{32}$ This presence of polymorphs in the nitrate family of ILs has been already studied and confirmed by several authors. ${ }^{32,37-40}$ Furthermore, the metastability of $\left[\mathrm{C}_{4} \mathrm{C}_{1} \mathrm{Im}\right] \mathrm{Cl}$ was herein noticed, with the melting temperature present in the second heating cycle at $T=342 \mathrm{~K}$ without further crystallizations in the following cycles. For this pure compound, a glass transition temperature was 
found at $T=231 \mathrm{~K}$. These results are in agreement with previous works which have evidenced the presence of a liquid-crystalline phase in metastable chloride based ILs. ${ }^{35,36}$ Furthermore, in the study of Yamamuro et. $a l,{ }^{36}$ the authors noticed that the IL did not crystallize at the fusion temperature in the cooling cycle. In this study, the crystal was only formed again when the temperature was cooled down to $T=200 \mathrm{~K}$ and annealed at $T=290 \mathrm{~K}$ for approximately one day. ${ }^{36}$ However, it should be noted that there are multiple measurements of ionic liquid transition temperatures determined by various groups and the results sometimes disagree since ionic liquids may be of different purities (most commonly, the impurities are water, or unreacted chemicals). 
Table 2. Experimental Melting Temperature, $T_{\mathrm{m}}$, Glass Transition Temperature, $T_{\mathrm{g}}$, Solid-Solid Transition Temperature, $T_{s-s}$, and Estimated Glass Transition Temperatures Via the $T_{0}$ Parameter of the Vogel-FulcherTammann (VFT) Equation, for the Pure Ionic Liquids. ${ }^{a}$ Many ILs Present an Empirical, $T_{\mathrm{g}} / T_{\mathrm{m}} \approx 2 / 3$ Golden Rule. Experimental Measurements Performed at an Average Atmospheric Pressure of $102 \mathrm{kPa}$

\begin{tabular}{|c|c|c|c|}
\hline & {$\left[\mathrm{C}_{4} \mathrm{C}_{1} \mathrm{Im}\right]\left[\mathrm{NO}_{3}\right]$} & {$\left[\mathrm{C}_{4} \mathrm{C}_{1} \mathrm{Im}\right]\left[\mathrm{CH}_{3} \mathrm{SO}_{3}\right]$} & {$\left[\mathrm{C}_{4} \mathrm{C}_{1} \mathrm{Im}\right] \mathrm{Cl}$} \\
\hline$T_{\mathrm{m}} / \mathrm{K}$ & 308 & 348 & 342 \\
\hline \multirow[t]{3}{*}{$T_{\mathrm{m}} / \mathrm{K}$ from literature } & $309.16^{32}$ & $350.25^{33}$ & $341.85^{35}$ \\
\hline & & $346.85^{34}$ & $341^{36}$ \\
\hline & & & $338^{31}$ \\
\hline \multirow[t]{3}{*}{$T_{\mathrm{g}} / \mathrm{K}$} & n.a. & $214^{b}$ & 231 \\
\hline & & & $230.75^{35}$ \\
\hline & & & $225^{36}$ \\
\hline \multirow[t]{2}{*}{$T_{s-s} / \mathrm{K}$} & 279 & & \\
\hline & 278.8 & & \\
\hline$T_{0}(\mathrm{VFT}) / \mathrm{K}$ & 185.7 & 191.3 & 214.2 \\
\hline$\left(T_{\mathrm{g}} / T_{\mathrm{m}}\right) \approx 2 / 3$ & & $0.6162^{b}$ & 0.6773 \\
\hline
\end{tabular}

${ }^{a}$ Standard uncertainties: $\mathrm{u}(T)=3 \mathrm{~K} ; \mathrm{u}(P)=1 \mathrm{kPa} ;{ }^{b}$ Hypothetical glass transition obtained by the linear extrapolation from the two ILs mixtures in which the IL $\left[\mathrm{C}_{4} \mathrm{C}_{1} \mathrm{Im}\right]\left[\mathrm{CH}_{3} \mathrm{SO}_{3}\right]$ is a component.

3.2. Solid-Liquid Phase Diagrams of the Ionic Liquids Mixtures. The solid-liquid equilibria (SLE) temperature-composition phase diagrams were determined using the temperature of the minimum of the DSC peaks for the mixtures. The experimental results are grouped in Tables 2-5 and illustrated in Figures 1-3. The SLE diagrams show two different types of phase behavior. Two binary mixtures $\left(\left[\mathrm{C}_{4} \mathrm{C}_{1} \mathrm{Im}\right]\left\{\left[\mathrm{NO}_{3}\right]_{(x)} \mathrm{Cl}_{(1-x)}\right\}\right.$ (see Figure 2 ) and $\left[\mathrm{C}_{4} \mathrm{C}_{1} \mathrm{Im}\right]\left\{\left[\mathrm{CH}_{3} \mathrm{SO}_{3}\right]_{(x)} \mathrm{Cl}_{(1-x)}\right\}$ (see Figure 3) exhibit the usual eutectic behavior associated with an ideal or quasi-ideal mutual solubility of solid compounds. The eutectic point occurs at around $T=302 \mathrm{~K}$ for $x_{[\mathrm{C} 4 \mathrm{ClIm}][\mathrm{NO} 3]} \approx$ 0.9 for the system $\left[\mathrm{C}_{4} \mathrm{C}_{1} \mathrm{Im}\right]\left\{\left[\mathrm{NO}_{3}\right]_{(\mathrm{x})} \mathrm{Cl}_{(1-\mathrm{x})}\right\}$ and around $T=321 \mathrm{~K}$ at $x_{[\mathrm{C} 4 \mathrm{C} 1 \mathrm{Im}][\mathrm{CH} 3 \mathrm{SO} 3]} \approx 0.45$ for the binary system $\left[\mathrm{C}_{4} \mathrm{C}_{1} \mathrm{Im}\right]\left\{\left[\mathrm{CH}_{3} \mathrm{SO}_{3}\right]_{(\mathrm{x})} \mathrm{Cl}_{(1-\mathrm{x})}\right\}$. Therefore, these mixtures present eutectic points close to room temperature. The chloride anion is small and it is able to hydrogen bond to two 
imidazolium cations at the same time, as it was demonstrated by the crystal structure. ${ }^{41}$ In contrast, the larger nitrate ${ }^{42}$ or methanesulfonate anions have weaker hydrogen bonding interactions.

The other binary mixture, $\left[\mathrm{C}_{4} \mathrm{C}_{1} \mathrm{Im}\right]\left\{\left[\mathrm{NO}_{3}\right]_{(x)}\left[\mathrm{CH}_{3} \mathrm{SO}_{3}\right]_{(1-x)}\right\}$, shows an interesting SLE behavior with the formation of a continuous solid solution (see Figure 1). This behavior revealed the complete miscibility of this binary mixture in the solid phase. The melting point temperatures decrease with the incorporation of $\left[\mathrm{C}_{4} \mathrm{C}_{1} \operatorname{Im}\right]\left[\mathrm{NO}_{3}\right]$ in the binary system. This SLE behavior has been previously found in other binary mixtures of ionic liquids ${ }^{43,44}$ where the ions are similar in size and are replaced by others that do not alter the crystal behavior of the components.

Figures 1-3 represent the glass transitions of the different binary mixtures. Taking into account that glasses are metastable with respect to crystallization, Tables 2-5 show the values calculated for the $T_{\mathrm{g}} / T_{\mathrm{m}}$ ratio which is known as the popular golden rule. ${ }^{45,46}$ This rule reveals that if a liquid fails to crystallize on cooling it will become a brittle glass at $2 / 3$ of its melting temperature. The pure compounds and their binary mixtures studied in this work show $T_{\mathrm{g}} / T_{\mathrm{m}}$ values at about an average value of $\approx 2 / 3(0.6666)$ following the golden rule. 
Table 3. Experimental SLE Temperature-Composition Data, $T$, Glass Transition Temperatures, $T_{\mathrm{g}}$, and $T_{\mathrm{g}} /$ $T_{\mathrm{m}}$ Ratio for $\left[\mathrm{C}_{4} \mathrm{C}_{1} \mathrm{Im}\right]\left\{\left[\mathrm{NO}_{3}\right]_{(x)}\left[\mathrm{CH}_{3} \mathrm{SO}_{3}\right]_{(1-x)}\right\}$ Mixtures ${ }^{a}$. Experimental Measurements Performed at an Average Atmospheric Pressure of $102 \mathrm{kPa}$

\begin{tabular}{|c|c|c|c|}
\hline$\left[\mathrm{C}_{4} \mathrm{C}_{1} \mathrm{Im}\right]\left\{\left[\mathrm{NO}_{3}\right]_{(x)}\left[\mathrm{CH}_{3} \mathrm{SO}_{3}\right]_{(1-x)}\right\}$ & $T / \mathrm{K}$ & $T_{\mathrm{g}} / \mathrm{K}$ & $T_{\mathrm{g}} / T_{\mathrm{m}}$ \\
\hline$\left[\mathrm{C}_{4} \mathrm{C}_{1} \mathrm{Im}\right]\left\{\left[\mathrm{NO}_{3}\right]_{0.1}\left[\mathrm{CH}_{3} \mathrm{SO}_{3}\right]_{0.9}\right\}$ & 345 & 214 & 0.6212 \\
\hline$\left[\mathrm{C}_{4} \mathrm{C}_{1} \mathrm{Im}\right]\left\{\left[\mathrm{NO}_{3}\right]_{0.2}\left[\mathrm{CH}_{3} \mathrm{SO}_{3}\right]_{0.8}\right\}$ & 344 & 215 & 0.6249 \\
\hline$\left[\mathrm{C}_{4} \mathrm{C}_{1} \mathrm{Im}\right]\left\{\left[\mathrm{NO}_{3}\right]_{0.3}\left[\mathrm{CH}_{3} \mathrm{SO}_{3}\right]_{0.7}\right\}$ & 331 & 204 & 0.6164 \\
\hline$\left[\mathrm{C}_{4} \mathrm{C}_{1} \mathrm{Im}\right]\left\{\left[\mathrm{NO}_{3}\right]_{0.4}\left[\mathrm{CH}_{3} \mathrm{SO}_{3}\right]_{0.6}\right\}$ & 327 & 206 & 0.6289 \\
\hline$\left[\mathrm{C}_{4} \mathrm{C}_{1} \mathrm{Im}\right]\left\{\left[\mathrm{NO}_{3}\right]_{0.5}\left[\mathrm{CH}_{3} \mathrm{SO}_{3}\right]_{0.5}\right\}$ & 325 & 209 & 0.6426 \\
\hline$\left[\mathrm{C}_{4} \mathrm{C}_{1} \mathrm{Im}\right]\left\{\left[\mathrm{NO}_{3}\right]_{0.6}\left[\mathrm{CH}_{3} \mathrm{SO}_{3}\right]_{0.4}\right\}$ & 315 & 204 & 0.6481 \\
\hline$\left[\mathrm{C}_{4} \mathrm{C}_{1} \mathrm{Im}\right]\left\{\left[\mathrm{NO}_{3}\right]_{0.7}\left[\mathrm{CH}_{3} \mathrm{SO}_{3}\right]_{0.3}\right\}$ & - & 202 & - \\
\hline$\left[\mathrm{C}_{4} \mathrm{C}_{1} \mathrm{Im}\right]\left\{\left[\mathrm{NO}_{3}\right]_{0.8}\left[\mathrm{CH}_{3} \mathrm{SO}_{3}\right]_{0.2}\right\}$ & 309 & 201 & 0.6511 \\
\hline$\left[\mathrm{C}_{4} \mathrm{C}_{1} \mathrm{Im}\right]\left\{\left[\mathrm{NO}_{3}\right]_{0.9}\left[\mathrm{CH}_{3} \mathrm{SO}_{3}\right]_{0.1}\right\}$ & 303 & 202 & 0.6672 \\
\hline
\end{tabular}

${ }^{a}$ Standard uncertainties: $\mathrm{u}(T)=3 \mathrm{~K}, \mathrm{u}(P)=1 \mathrm{kPa}$ and $\mathrm{u}(x)=0.004$ in molar fraction. 
Table 4. Experimental SLE Temperature-Composition Data, $T$, Glass Transition Temperatures, $T_{\mathrm{g}}$, and $T_{\mathrm{g}} /$ $T_{\mathrm{m}}$ Ratio for $\left[\mathrm{C}_{4} \mathrm{C}_{1} \mathrm{Im}\right]\left\{\left[\mathrm{NO}_{3}\right]_{(x)} \mathrm{Cl}_{(1-x)}\right\}$ Mixtures ${ }^{a}$. Experimental Measurements Performed at an Average Atmospheric Pressure of $102 \mathrm{kPa}$

\begin{tabular}{llll}
\hline$\left[\mathrm{C}_{4} \mathrm{C}_{1} \mathrm{Im}\right]\left\{\left[\mathrm{NO}_{3}\right]_{(x)} \mathrm{Cl}_{(1-x)}\right\}$ & $T / \mathrm{K}$ & $T_{\mathrm{g}} / \mathrm{K}$ & $T_{\mathrm{g}} / T_{\mathrm{m}}$ \\
\hline$\left[\mathrm{C}_{4} \mathrm{C}_{1} \mathrm{Im}\right]\left\{\left[\mathrm{NO}_{3}\right]_{0.1} \mathrm{Cl}_{0.9}\right\}$ & 324 & 238 & 0.7351 \\
{$\left[\mathrm{C}_{4} \mathrm{C}_{1} \mathrm{Im}\right]\left\{\left[\mathrm{NO}_{3}\right]_{0.2} \mathrm{Cl}_{0.8}\right\}$} & 322 & 220 & 0.6832 \\
{$\left[\mathrm{C}_{4} \mathrm{C}_{1} \mathrm{Im}\right]\left\{\left[\mathrm{NO}_{3}\right]_{0.3} \mathrm{Cl}_{0.7}\right\}$} & 325 & 217 & 0.6696 \\
{$\left[\mathrm{C}_{4} \mathrm{C}_{1} \mathrm{Im}\right]\left\{\left[\mathrm{NO}_{3}\right]_{0.4} \mathrm{Cl}_{0.6}\right\}$} & 315 & 212 & 0.6741 \\
$\left.\mathrm{C}_{4} \mathrm{C}_{1} \mathrm{Im}\right]\left\{\left[\mathrm{NO}_{3}\right]_{0.5} \mathrm{Cl}_{0.5}\right\}$ & 302 & & \\
& 313 & 213 & 0.6799 \\
{$\left[\mathrm{C}_{4} \mathrm{C}_{1} \mathrm{Im}\right]\left\{\left[\mathrm{NO}_{3}\right]_{0.6} \mathrm{Cl}_{0.4}\right\}$} & 302 & & \\
& 313 & 211 & 0.6750 \\
{$\left[\mathrm{C}_{4} \mathrm{C}_{1} \mathrm{Im}\right]\left\{\left[\mathrm{NO}_{3}\right]_{0.7} \mathrm{Cl}_{0.3}\right\}$} & 301 & & \\
& 312 & 208 & 0.6650 \\
{$\left[\mathrm{C}_{4} \mathrm{C}_{1} \mathrm{Im}\right]\left\{\left[\mathrm{NO}_{3}\right]_{0.8} \mathrm{Cl}_{0.2}\right\}$} & 303 & 207 & 0.6820 \\
{$\left[\mathrm{C}_{4} \mathrm{C}_{1} \mathrm{Im}\right]\left\{\left[\mathrm{NO}_{3}\right]_{0.9} \mathrm{Cl}_{0.1}\right\}$} & 302 & 204 & 0.6768 \\
{$\left[\mathrm{C}_{4} \mathrm{C}_{1} \mathrm{Im}\right]\left\{\left[\mathrm{NO}_{3}\right]_{0.95} \mathrm{Cl}_{0.05}\right\}$} & 303 & 204 & \\
\hline $\mathrm{S}_{2}$ & 305 & & 0.6681 \\
\hline
\end{tabular}

${ }^{a}$ Standard uncertainties: $\mathrm{u}(T)=3 \mathrm{~K}, \mathrm{u}(P)=1 \mathrm{kPa}$ and $\mathrm{u}(x)=0.004$ in molar fraction. 
Table 5. Experimental SLE Temperature-Composition Data, $T$, Glass Transition Temperatures, $T_{\mathrm{g}}$, and $T_{\mathrm{g}} /$ $T_{\mathrm{m}}$ Ratio for $\left[\mathrm{C}_{4} \mathrm{C}_{1} \mathrm{Im}\right]\left\{\left[\mathrm{CH}_{3} \mathrm{SO}_{3}\right]_{(x)} \mathrm{Cl}_{(1-x)}\right\}$ Mixtures ${ }^{a}$. Experimental Measurements Performed at an Average Atmospheric Pressure of $102 \mathrm{kPa}$

\begin{tabular}{lccc}
\hline$\left[\mathrm{C}_{4} \mathrm{C}_{1} \mathrm{Im}\right]\left\{\left[\mathrm{NO}_{3}\right]_{(x)}\left[\mathrm{CH}_{3} \mathrm{SO}_{3}\right]_{(1-x)}\right\}$ & $T / \mathrm{K}$ & $T_{\mathrm{g}} / \mathrm{K}$ & 0.6856 \\
\hline$\left[\mathrm{C}_{4} \mathrm{C}_{1} \mathrm{Im}\right]\left\{\left[\mathrm{CH}_{3} \mathrm{SO}_{3}\right]_{0.1} \mathrm{Cl}_{0.9}\right\}$ & 333 & 228 & 0.6888 \\
{$\left[\mathrm{C}_{4} \mathrm{C}_{1} \mathrm{Im}\right]\left\{\left[\mathrm{CH}_{3} \mathrm{SO}_{3}\right]_{0.2} \mathrm{Cl}_{0.8}\right\}$} & 326 & 225 & 0.6982 \\
{$\left[\mathrm{C}_{4} \mathrm{C}_{1} \mathrm{Im}\right]\left\{\left[\mathrm{CH}_{3} \mathrm{SO}_{3}\right]_{0.3} \mathrm{Cl}_{0.7}\right\}$} & 319 & 223 & 0.6946 \\
{$\left[\mathrm{C}_{4} \mathrm{C}_{1} \mathrm{Im}\right]\left\{\left[\mathrm{CH}_{3} \mathrm{SO}_{3}\right]_{0.35} \mathrm{Cl}_{0.65}\right\}$} & 321 & 223 & 0.7047 \\
{$\left[\mathrm{C}_{4} \mathrm{C}_{1} \mathrm{Im}\right]\left\{\left[\mathrm{CH}_{3} \mathrm{SO}_{3}\right]_{0.4} \mathrm{Cl}_{0.6}\right\}$} & 322 & 227 & 0.6830 \\
{$\left[\mathrm{C}_{4} \mathrm{C}_{1} \mathrm{Im}\right]\left\{\left[\mathrm{CH}_{3} \mathrm{SO}_{3}\right]_{0.45} \mathrm{Cl}_{0.55}\right\}$} & 321 & 219 & 0.6908 \\
{$\left[\mathrm{C}_{4} \mathrm{C}_{1} \mathrm{Im}\right]\left\{\left[\mathrm{CH}_{3} \mathrm{SO}_{3}\right]_{0.5} \mathrm{Cl}_{0.5}\right\}$} & 321 & 222 & 0.6724 \\
{$\left[\mathrm{C}_{4} \mathrm{C}_{1} \mathrm{Im}\right]\left\{\left[\mathrm{CH}_{3} \mathrm{SO}_{3}\right]_{0.6} \mathrm{Cl}_{0.4}\right\}$} & 331 & 223 & 0.6754 \\
{$\left[\mathrm{C}_{4} \mathrm{C}_{1} \mathrm{Im}\right]\left\{\left[\mathrm{CH}_{3} \mathrm{SO}_{3}\right]_{0.7} \mathrm{Cl}_{0.3}\right\}$} & 336 & 221 & 0.6377 \\
{$\left[\mathrm{C}_{4} \mathrm{C}_{1} \mathrm{Im}\right]\left\{\left[\mathrm{CH}_{3} \mathrm{SO}_{3}\right]_{0.8} \mathrm{Cl}_{0.2}\right\}$} & 339 & 216 & 0.6259 \\
{$\left[\mathrm{C}_{4} \mathrm{C}_{1} \mathrm{Im}\right]\left\{\left[\mathrm{CH}_{3} \mathrm{SO}_{3}\right]_{0.9} \mathrm{Cl}_{0.1}\right\}$} & 345 & 216 & \\
\hline
\end{tabular}

${ }^{a}$ Standard uncertainties: $\mathrm{u}(T)=3 \mathrm{~K}, \mathrm{u}(P)=1 \mathrm{kPa}$ and $\mathrm{u}(x)=0.004$ in molar fraction. 


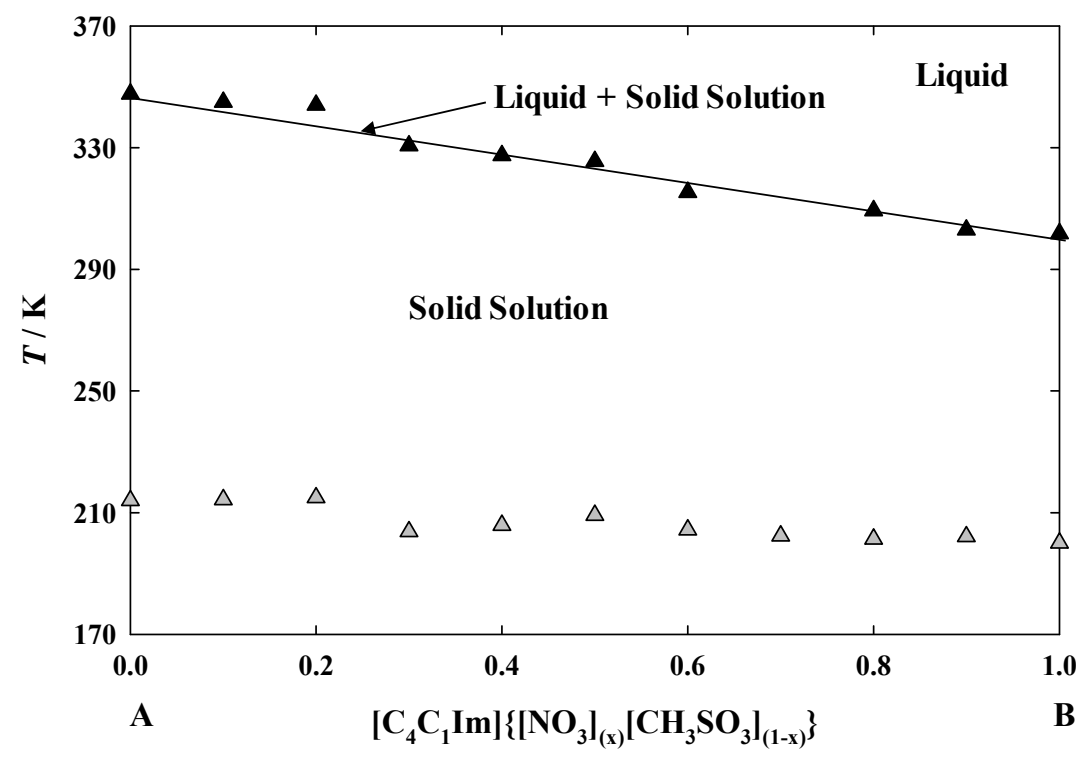

Figure 1. Solid-liquid phase diagram of the mixture $\left[\mathrm{C}_{4} \mathrm{C}_{1} \mathrm{Im}\right]\left\{\left[\mathrm{NO}_{3}\right]_{(\mathrm{x})}\left[\mathrm{CH}_{3} \mathrm{SO}_{3}\right]_{(1-\mathrm{x})}\right\}$, temperature versus mole fraction of $\left[\mathrm{C}_{4} \mathrm{C}_{1} \mathrm{Im}\right]\left[\mathrm{NO}_{3}\right]$ : solid-liquid transition, $\boldsymbol{\Delta}$; and glass transition temperature, $\triangle$. The solid lines are just guides to the eye representing the boundary between the phase regions.

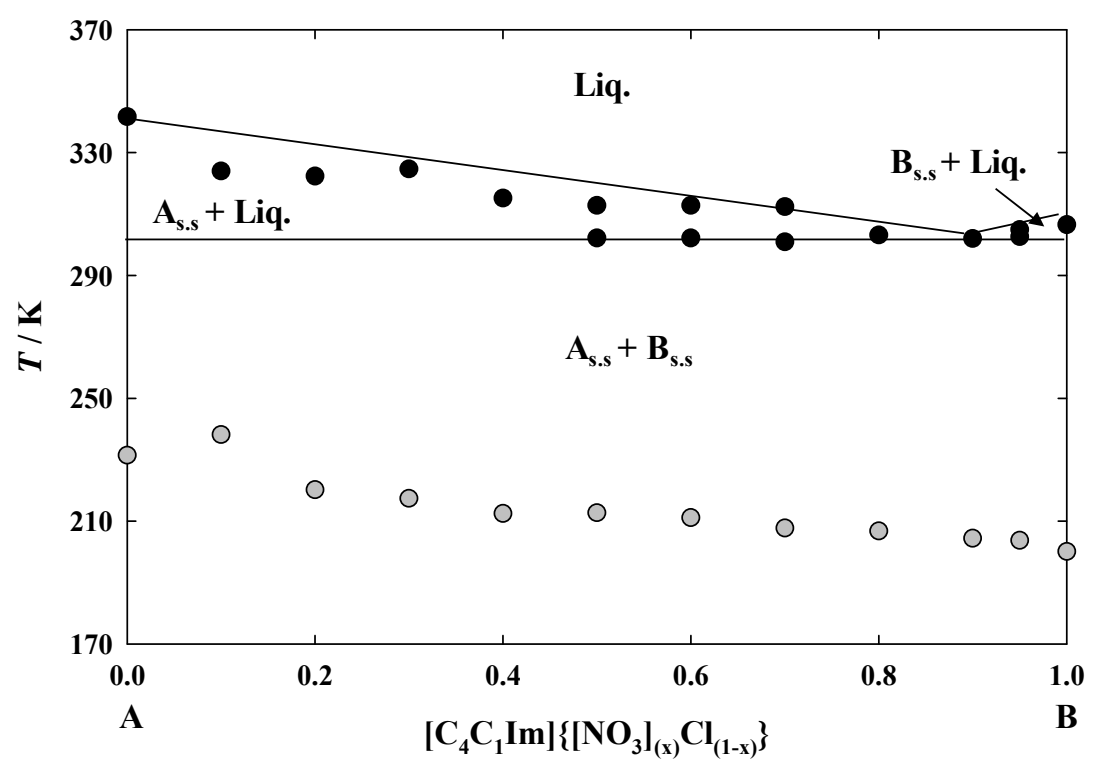

Figure 2. Solid-liquid phase diagram of the mixture $\left[\mathrm{C}_{4} \mathrm{C}_{1} \mathrm{Im}\right]\left\{\left[\mathrm{NO}_{3}\right]_{(\mathrm{x})} \mathrm{Cl}_{(1-\mathrm{x})}\right\}$, temperature versus mole fraction of $\left[\mathrm{C}_{4} \mathrm{C}_{1} \mathrm{Im}\right]\left[\mathrm{NO}_{3}\right]$ : solid-liquid transition, $\bullet$; and glass transition temperature, $\bullet$. The solid lines are just guides to the eye representing the boundary between the phase regions. 


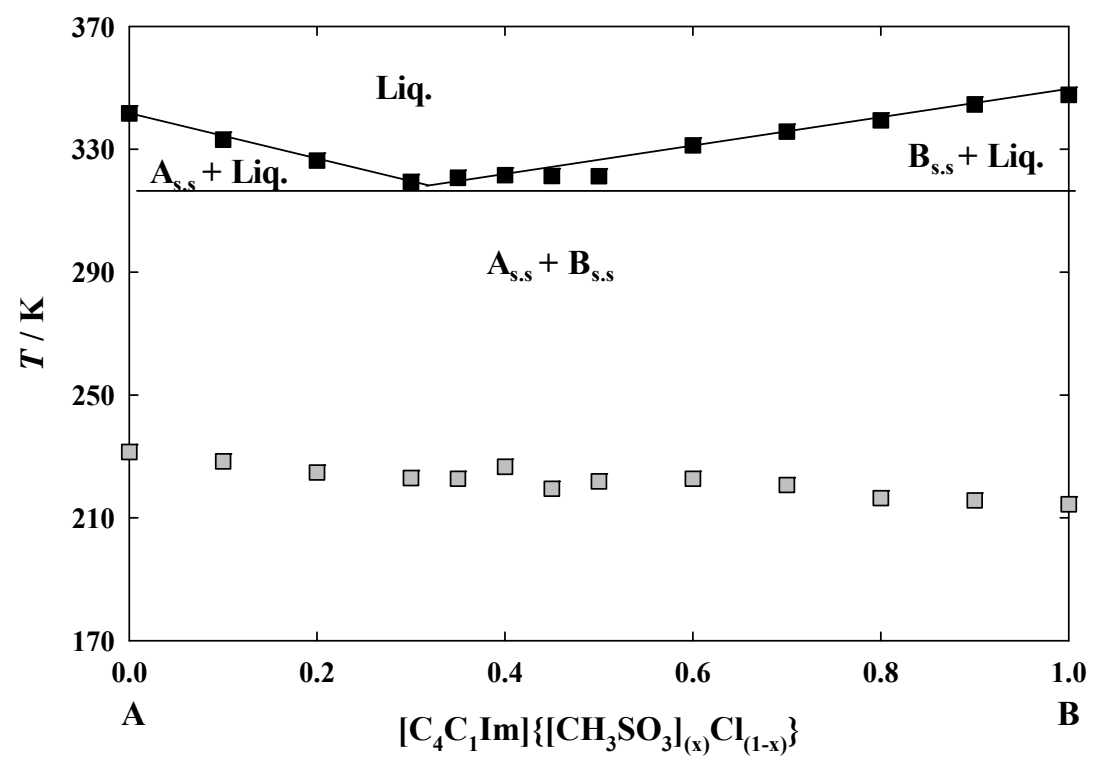

Figure 3. Solid-liquid phase diagram of the mixture $\left[\mathrm{C}_{4} \mathrm{C}_{1} \mathrm{Im}\right]\left\{\left[\mathrm{CH}_{3} \mathrm{SO}_{3}\right]_{(\mathrm{x})} \mathrm{Cl}_{(1-\mathrm{x})}\right\}$, temperature versus mole fraction of $\left[\mathrm{C}_{4} \mathrm{C}_{1} \mathrm{Im}\right]\left[\mathrm{CH}_{3} \mathrm{SO}_{3}\right]$ : solid-liquid transition, $\mathbf{m}$; and glass transition temperature, $\square$. The solid lines are just guides to the eye representing the boundary between the phase regions. 
3.3. Density and Viscosity. For any compounds used in industrial and chemical applications the determination of fluid phase properties, such as the density and viscosity of the pure ILs and their binary mixtures is of crucial relevance. Density displays a very important role regarding the selection of the most appropriate compounds to be used in different purposes. ${ }^{2,47-49}$ The results for the pure ILs are depicted in Table S5 and Figure S10 of SI. In Table S6 of SI, a comparison with published values is shown. We are not aware of any previous experimental determinations of either density or viscosity for any of the studied binary mixtures. Our results are presented in Tables 6-8 and illustrated in Figures 4-9. Based on our results, it was possible to state that the increment of the $\left[\mathrm{C}_{4} \mathrm{C}_{1} \mathrm{Im}\right]\left[\mathrm{NO}_{3}\right]$ molar fraction leads to a decrease of both density and viscosity for the $\left[\mathrm{C}_{4} \mathrm{C}_{1} \mathrm{Im}\right]\left\{\left[\mathrm{NO}_{3}\right]_{(x)}\left[\mathrm{CH}_{3} \mathrm{SO}_{3}\right]_{(1-x)}\right\}$ mixture. The other systems, $\left[\mathrm{C}_{4} \mathrm{C}_{1} \mathrm{Im}\right]\left\{\left[\mathrm{NO}_{3}\right]_{(x)} \mathrm{Cl}_{(1-x)}\right\}$ and $\left[\mathrm{C}_{4} \mathrm{C}_{1} \mathrm{Im}\right]\left\{\left[\mathrm{CH}_{3} \mathrm{SO}_{3}\right](x) \mathrm{Cl}_{(1-x)}\right\}$, which contain the $\left[\mathrm{C}_{4} \mathrm{C}_{1} \mathrm{Im}\right] \mathrm{Cl}$ salt, reveal a similar behavior. In these mixtures, the increment of the $\left[\mathrm{C}_{4} \mathrm{C}_{1} \mathrm{Im}\right] \mathrm{Cl}$ molar composition leads to a reduction of density. An opposite behavior is observed in the viscosity trends. These results suggest that the chloride anion might play a major role on the thermophysical behavior of the mixtures which can be related to the hydrogen bonding capacity of this anion when is compared with the other anions used in this work. 
The temperature dependence of the density was determined applying the following expression for both pure ILs and their binary mixtures:

$\ln \left(\rho / \mathrm{g} \cdot \mathrm{cm}^{-3}\right)=A_{0}+A_{1} \cdot(T / \mathrm{K})$

where $T$ is the absolute temperature and $A_{0}$, and $A_{1}$ are adjustable parameters. The correlation parameters are given in Table S7 of the SI together with the standard deviations (S. D.) which were calculated using the following expression:

S.D. $=\left(\frac{\sum_{\mathrm{i}}^{n_{\mathrm{DAT}}}\left(z_{\text {exp }}-z_{\text {adjust }}\right)^{2}}{n_{\mathrm{DAT}}}\right)^{1 / 2}$

where property values and the number of experimental and adjustable data are represented by $z$ and $n$ DAT, respectively. 
Table 6. Density, $\rho$, and Viscosity, $\eta$, of $\left[\mathrm{C}_{4} \mathrm{C}_{1} \mathrm{Im}\right]\left\{\left[\mathrm{NO}_{3}\right]_{(\mathrm{x})}\left[\mathrm{CH}_{3} \mathrm{SO}_{3}\right]_{(1-\mathrm{x})}\right\}$ Mixtures ${ }^{a}$. Experimental Measurements Performed at an Average Atmospheric Pressure of $102 \mathrm{kPa}$

\begin{tabular}{|c|c|c|c|c|c|}
\hline$T / \mathrm{K}$ & $\rho / \mathrm{g} \cdot \mathrm{cm}^{-3}$ & $\eta / \mathrm{mPa} \cdot \mathrm{s}$ & $T / \mathrm{K}$ & $\rho / \mathrm{g} \cdot \mathrm{cm}^{-3}$ & $\eta / \mathrm{mPa} \cdot \mathrm{s}$ \\
\hline \multicolumn{3}{|c|}{$\left[\mathrm{C}_{4} \mathrm{C}_{1} \mathrm{Im}\right]\left\{\left[\mathrm{NO}_{3}\right]_{0.1}\left[\mathrm{CH}_{3} \mathrm{SO}_{3}\right]_{0.9}\right\}$} & \multicolumn{3}{|c|}{$\left[\mathrm{C}_{4} \mathrm{C}_{1} \mathrm{Im}\right]\left\{\left[\mathrm{NO}_{3}\right]_{0.2}\left[\mathrm{CH}_{3} \mathrm{SO}_{3}\right]_{0.8}\right\}$} \\
\hline 348.15 & 1.1383 & 34.98 & 348.15 & 1.1368 & 34.50 \\
\hline 353.15 & 1.1352 & 29.38 & 353.15 & 1.1336 & 29.04 \\
\hline 358.15 & 1.1320 & 24.94 & 358.15 & 1.1305 & 24.71 \\
\hline 363.15 & 1.1289 & 21.39 & 363.15 & 1.1274 & 21.27 \\
\hline \multicolumn{3}{|c|}{$\left[\mathrm{C}_{4} \mathrm{C}_{1} \mathrm{Im}\right]\left\{\left[\mathrm{NO}_{3}\right]_{0.3}\left[\mathrm{CH}_{3} \mathrm{SO}_{3}\right]_{0.7}\right\}$} & \multicolumn{3}{|c|}{$\left[\mathrm{C}_{4} \mathrm{C}_{1} \mathrm{Im}\right]\left\{\left[\mathrm{NO}_{3}\right]_{0.4}\left[\mathrm{CH}_{3} \mathrm{SO}_{3}\right]_{0.6}\right\}$} \\
\hline 333.15 & 1.1449 & 59.13 & 328.15 & 1.1469 & 70.76 \\
\hline 338.15 & 1.1418 & 48.04 & 333.15 & 1.1438 & 56.85 \\
\hline 343.15 & 1.1386 & 39.58 & 338.15 & 1.1406 & 46.37 \\
\hline 348.15 & 1.1355 & 33.03 & 343.15 & 1.1375 & 38.34 \\
\hline 353.15 & 1.1324 & 27.88 & 348.15 & 1.1344 & 32.10 \\
\hline 358.15 & 1.1293 & 23.79 & 353.15 & 1.1313 & 27.17 \\
\hline 363.15 & 1.1262 & 20.51 & 358.15 & 1.1282 & 23.23 \\
\hline- & - & - & 363.15 & 1.1251 & 20.04 \\
\hline \multicolumn{3}{|c|}{$\left[\mathrm{C}_{4} \mathrm{C}_{1} \mathrm{Im}\right]\left\{\left[\mathrm{NO}_{3}\right]_{0.5}\left[\mathrm{CH}_{3} \mathrm{SO}_{3}\right]_{0.5}\right\}$} & \multicolumn{3}{|c|}{$\left[\mathrm{C}_{4} \mathrm{C}_{1} \mathrm{Im}\right]\left\{\left[\mathrm{NO}_{3}\right]_{0.6}\left[\mathrm{CH}_{3} \mathrm{SO}_{3}\right]_{0.4}\right\}$} \\
\hline 328.15 & 1.1454 & 66.57 & 318.15 & 1.1505 & 103.0 \\
\hline 333.15 & 1.1422 & 53.70 & 323.15 & 1.1473 & 80.70 \\
\hline 338.15 & 1.1391 & 43.99 & 328.15 & 1.1441 & 64.37 \\
\hline 343.15 & 1.1360 & 36.52 & 333.15 & 1.1410 & 52.18 \\
\hline 348.15 & 1.1329 & 30.69 & 338.15 & 1.1379 & 42.90 \\
\hline 353.15 & 1.1298 & 26.08 & 343.15 & 1.1348 & 35.74 \\
\hline 358.15 & 1.1268 & 22.38 & 348.15 & 1.1317 & 30.13 \\
\hline 363.15 & 1.1237 & 19.36 & 353.15 & 1.1286 & 25.68 \\
\hline- & - & - & 358.15 & 1.1256 & 22.09 \\
\hline- & - & - & 363.15 & 1.1225 & 19.18 \\
\hline \multicolumn{3}{|c|}{$\left[\mathrm{C}_{4} \mathrm{C}_{1} \mathrm{Im}\right]\left\{\left[\mathrm{NO}_{3}\right]_{0.7}\left[\mathrm{CH}_{3} \mathrm{SO}_{3}\right]_{0.3}\right\}$} & \multicolumn{3}{|c|}{$\left[\mathrm{C}_{4} \mathrm{C}_{1} \mathrm{Im}\right]\left\{\left[\mathrm{NO}_{3}\right]_{0.8}\left[\mathrm{CH}_{3} \mathrm{SO}_{3}\right]_{0.2}\right\}$} \\
\hline 318.15 & 1.1485 & 97.85 & 313.15 & 1.1493 & 113.6 \\
\hline 323.15 & 1.1454 & 77.05 & 318.15 & 1.1462 & 88.38 \\
\hline 328.15 & 1.1422 & 61.72 & 323.15 & 1.1430 & 70.03 \\
\hline 333.15 & 1.1391 & 50.22 & 328.15 & 1.1399 & 56.42 \\
\hline 338.15 & 1.1360 & 41.44 & 333.15 & 1.1368 & 46.14 \\
\hline 343.15 & 1.1329 & 34.63 & 338.15 & 1.1337 & 38.25 \\
\hline 348.15 & 1.1299 & 29.28 & 343.15 & 1.1306 & 32.11 \\
\hline 353.15 & 1.1268 & 25.02 & 348.15 & 1.1276 & 27.25 \\
\hline 358.15 & 1.1238 & 21.57 & 353.15 & 1.1245 & 23.36 \\
\hline
\end{tabular}




\begin{tabular}{cccccc}
363.15 & 1.1207 & 18.76 & 358.15 & 1.1215 & 20.21 \\
- & - & - & 363.15 & 1.1185 & 17.63 \\
303.15 & 1.1543 & {$\left[\mathrm{C}_{4} \mathrm{C}_{1} \mathrm{Im}\right]\left\{\left[\mathrm{NO}_{3}\right]_{0.9}\left[\mathrm{CH}_{3} \mathrm{SO}_{3}\right]_{0.1}\right\}$} & & \\
308.15 & 1.1511 & 180.1 & 338.15 & 1.1323 & 35.99 \\
313.15 & 1.1479 & 135.4 & 343.15 & 1.1293 & 30.32 \\
318.15 & 1.1447 & 81.49 & 353.15 & 1.1232 & 22.81 \\
323.15 & 1.1416 & 64.96 & 358.15 & 1.1202 & 19.26 \\
328.15 & 1.1385 & 52.61 & 363.15 & 1.1172 & 16.86 \\
333.15 & 1.1354 & 43.23 & & & \\
\hline${ }^{a}$ Sandard
\end{tabular}

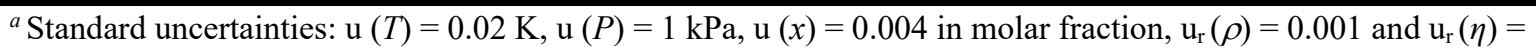
0.02 . 
Table 7. Density, $\rho$, and Viscosity, $\eta$, of $\left[\mathrm{C}_{4} \mathrm{C}_{1} \mathrm{Im}\right]\left\{\left[\mathrm{NO}_{3}\right]_{(x)} \mathrm{Cl}_{(1-x)\}}\right\}$ Mixtures ${ }^{a}$. Experimental Measurements Performed at an Average Atmospheric Pressure of $102 \mathrm{kPa}$

\begin{tabular}{|c|c|c|c|c|c|}
\hline$T / \mathrm{K}$ & $\rho / \mathrm{g} \cdot \mathrm{cm}^{-3}$ & $\eta / \mathrm{mPa} \cdot \mathrm{s}$ & $T / \mathrm{K}$ & $\rho / \mathrm{g} \cdot \mathrm{cm}^{-3}$ & $\eta / \mathrm{mPa} \cdot \mathrm{s}$ \\
\hline \multicolumn{3}{|c|}{$\left[\mathrm{C}_{4} \mathrm{C}_{1} \mathrm{Im}\right]\left\{\left[\mathrm{NO}_{3}\right]_{0.1} \mathrm{Cl}_{0.9}\right\}$} & \multicolumn{3}{|c|}{$\left[\mathrm{C}_{4} \mathrm{C}_{1} \mathrm{Im}\right]\left\{\left[\mathrm{NO}_{3}\right]_{0.2} \mathrm{Cl}_{0.8}\right\}$} \\
\hline 333.15 & 1.0703 & 378.4 & 318.15 & - & 721.3 \\
\hline 338.15 & 1.0675 & 271.8 & 323.15 & - & 495.6 \\
\hline 343.15 & 1.0648 & 199.9 & 328.15 & 1.0802 & 349.9 \\
\hline 348.15 & 1.0621 & 150.1 & 333.15 & 1.0773 & 253.4 \\
\hline 353.15 & 1.0593 & 115.0 & 338.15 & 1.0744 & 187.6 \\
\hline 358.15 & 1.0566 & 89.62 & 343.15 & 1.0716 & 141.9 \\
\hline 363.15 & 1.0538 & 71.03 & 348.15 & 1.0688 & 109.3 \\
\hline- & - & - & 353.15 & 1.0659 & 85.68 \\
\hline- & - & - & 358.15 & 1.0631 & 68.25 \\
\hline- & - & - & 363.15 & 1.0604 & 55.17 \\
\hline \multicolumn{3}{|c|}{$\left[\mathrm{C}_{4} \mathrm{C}_{1} \mathrm{Im}\right]\left\{\left[\mathrm{NO}_{3}\right]_{0.4} \mathrm{Cl}_{0.6}\right\}$} & \multicolumn{3}{|c|}{$\left[\mathrm{C}_{4} \mathrm{C}_{1} \mathrm{Im}\right]\left\{\left[\mathrm{NO}_{3}\right]_{0.5} \mathrm{Cl}_{0.5}\right\}$} \\
\hline 323.15 & 1.0979 & 259.8 & 313.15 & 1.1096 & 365.1 \\
\hline 328.15 & 1.0950 & 191.3 & 318.15 & 1.1066 & 262.7 \\
\hline 333.15 & 1.0920 & 144.0 & 323.15 & 1.1037 & 193.7 \\
\hline 338.15 & 1.0891 & 110.6 & 328.15 & 1.1008 & 145.9 \\
\hline 343.15 & 1.0862 & 86.47 & 333.15 & 1.0979 & 112.0 \\
\hline 348.15 & 1.0833 & 68.73 & 338.15 & 1.0950 & 87.65 \\
\hline 353.15 & 1.0805 & 55.46 & 343.15 & 1.0921 & 69.70 \\
\hline 358.15 & 1.0776 & 45.37 & 348.15 & 1.0892 & 56.25 \\
\hline \multirow[t]{3}{*}{363.15} & 1.0748 & 37.60 & 353.15 & 1.0864 & 46.03 \\
\hline & & & 358.15 & 1.0835 & 38.16 \\
\hline & & & 363.15 & 1.0806 & 32.02 \\
\hline \multicolumn{3}{|c|}{$\left[\mathrm{C}_{4} \mathrm{C}_{1} \mathrm{Im}\right]\left\{\left[\mathrm{NO}_{3}\right]_{0.6} \mathrm{Cl}_{0.4}\right\}$} & \multicolumn{3}{|c|}{$\left[\mathrm{C}_{4} \mathrm{C}_{1} \mathrm{Im}\right]\left\{\left[\mathrm{NO}_{3}\right]_{0.8} \mathrm{Cl}_{0.2}\right\}$} \\
\hline 313.15 & 1.1169 & 275.4 & 298.15 & 1.1399 & 373.6 \\
\hline 318.15 & 1.1139 & 201.5 & 303.15 & 1.1368 & 266.4 \\
\hline 323.15 & 1.1109 & 150.8 & 308.15 & 1.1337 & 194.9 \\
\hline 328.15 & 1.1079 & 115.2 & 313.15 & 1.1306 & 146.0 \\
\hline 333.15 & 1.1049 & 89.66 & 318.15 & 1.1276 & 111.7 \\
\hline 338.15 & 1.1019 & 71.02 & 323.15 & 1.1246 & 87.10 \\
\hline 343.15 & 1.0990 & 57.14 & 328.15 & 1.1216 & 69.09 \\
\hline 348.15 & 1.0961 & 46.63 & 333.15 & 1.1186 & 55.68 \\
\hline 353.15 & 1.0932 & 38.55 & 338.15 & 1.1157 & 45.53 \\
\hline 358.15 & 1.0903 & 32.27 & 343.15 & 1.1127 & 37.72 \\
\hline
\end{tabular}




\begin{tabular}{cccccc}
363.15 & 1.0874 & 27.32 & 348.15 & 1.1097 & 31.62 \\
- & - & - & 353.15 & 1.1068 & 26.81 \\
- & - & - & 358.15 & 1.1038 & 22.96 \\
- & - & - & 363.15 & 1.1009 & 19.87 \\
\hline${ }^{a}$ Standard uncertainties: $\mathrm{u}(T)=0.02 \mathrm{~K}, \mathrm{u}(P)=1 \mathrm{kPa}, \mathrm{u}(x)=0.004$ in
\end{tabular}

${ }^{a}$ Standard uncertainties: $\mathrm{u}(T)=0.02 \mathrm{~K}, \mathrm{u}(P)=1 \mathrm{kPa}, \mathrm{u}(x)=0.004$ in molar fraction, $\mathrm{u}_{\mathrm{r}}(\rho)=0.001$ and $\mathrm{u}_{\mathrm{r}}(\eta)=$ 0.02 . 
Table 8. Density, $\rho$, and Viscosity, $\eta$, of $\left[\mathrm{C}_{4} \mathrm{C}_{1} \mathrm{Im}\right]\left\{\left[\mathrm{CH}_{3} \mathrm{SO}_{3}\right]_{(\mathrm{x})} \mathrm{Cl}_{(1-\mathrm{x})}\right\}$ Mixtures ${ }^{a}$. Experimental Measurements Performed at an Average Atmospheric Pressure of $102 \mathrm{kPa}$

\begin{tabular}{|c|c|c|c|c|c|}
\hline$T / \mathrm{K}$ & $\rho / \mathrm{g} \cdot \mathrm{cm}^{-3}$ & $\eta / \mathrm{mPa} \cdot \mathrm{s}$ & $T / \mathrm{K}$ & $\rho / \mathrm{g} \cdot \mathrm{cm}^{-3}$ & $\eta / \mathrm{mPa} \cdot \mathrm{s}$ \\
\hline \multicolumn{3}{|c|}{$\left[\mathrm{C}_{4} \mathrm{C}_{1} \mathrm{Im}\right]\left\{\left[\mathrm{CH}_{3} \mathrm{SO}_{3}\right]_{0.1} \mathrm{Cl}_{0.9}\right\}$} & \multicolumn{3}{|c|}{$\left[\mathrm{C}_{4} \mathrm{C}_{1} \mathrm{Im}\right]\left\{\left[\mathrm{CH}_{3} \mathrm{SO}_{3}\right]_{0.2} \mathrm{Cl}_{0.8}\right\}$} \\
\hline 328.15 & 1.0767 & 490.5 & 328.15 & 1.0861 & 428.3 \\
\hline 333.15 & 1.0740 & 346.3 & 333.15 & 1.0834 & 304.6 \\
\hline 338.15 & 1.0714 & 250.7 & 338.15 & 1.0807 & 222.0 \\
\hline 343.15 & 1.0687 & 185.6 & 343.15 & 1.0780 & 165.4 \\
\hline 348.15 & 1.0661 & 140.3 & 348.15 & 1.0754 & 125.8 \\
\hline 353.15 & 1.0635 & 108.1 & 353.15 & 1.0728 & 97.50 \\
\hline 358.15 & 1.0609 & 84.67 & 358.15 & 1.0701 & 76.85 \\
\hline 363.15 & 1.0582 & 67.42 & 363.15 & 1.0673 & 61.54 \\
\hline \multicolumn{3}{|c|}{$\left[\mathrm{C}_{4} \mathrm{C}_{1} \mathrm{Im}\right]\left\{\left[\mathrm{CH}_{3} \mathrm{SO}_{3}\right]_{0.3} \mathrm{Cl}_{0.7}\right\}$} & \multicolumn{3}{|c|}{$\left[\mathrm{C}_{4} \mathrm{C}_{1} \mathrm{Im}\right]\left\{\left[\mathrm{CH}_{3} \mathrm{SO}_{3}\right]_{0.4} \mathrm{Cl}_{0.6}\right\}$} \\
\hline 323.15 & 1.0989 & 388.2 & 323.15 & 1.1063 & 365.5 \\
\hline 328.15 & 1.0961 & 278.2 & 328.15 & 1.1034 & 261.8 \\
\hline 333.15 & 1.0933 & 204.2 & 333.15 & 1.1006 & 192.2 \\
\hline 338.15 & 1.0906 & 153.2 & 338.15 & 1.0979 & 144.3 \\
\hline 343.15 & 1.0879 & 117.2 & 343.15 & 1.0952 & 110.5 \\
\hline 348.15 & 1.0852 & 91.36 & 348.15 & 1.0925 & 86.21 \\
\hline 353.15 & 1.0825 & 72.39 & 353.15 & 1.0897 & 68.40 \\
\hline 358.15 & 1.0798 & 58.23 & 358.15 & 1.0869 & 55.11 \\
\hline 363.15 & 1.0770 & 47.51 & 363.15 & 1.0841 & 45.04 \\
\hline \multicolumn{3}{|c|}{$\left[\mathrm{C}_{4} \mathrm{C}_{1} \mathrm{Im}\right]\left\{\left[\mathrm{CH}_{3} \mathrm{SO}_{3}\right]_{0.5} \mathrm{Cl}_{0.5}\right\}$} & \multicolumn{3}{|c|}{$\left[\mathrm{C}_{4} \mathrm{C}_{1} \mathrm{Im}\right]\left\{\left[\mathrm{CH}_{3} \mathrm{SO}_{3}\right]_{0.6} \mathrm{Cl}_{0.4}\right\}$} \\
\hline 323.15 & 1.1166 & 267.1 & 333.15 & 1.1191 & 128.0 \\
\hline 328.15 & 1.1137 & 195.6 & 338.15 & 1.1163 & 98.76 \\
\hline 333.15 & 1.1109 & 146.5 & 343.15 & 1.1135 & 77.62 \\
\hline 338.15 & 1.1081 & 112.1 & 348.15 & 1.1107 & 62.01 \\
\hline 343.15 & 1.1053 & 87.31 & 353.15 & 1.1079 & 50.28 \\
\hline 348.15 & 1.1026 & 69.19 & 358.15 & 1.1050 & 41.33 \\
\hline 353.15 & 1.0998 & 55.70 & 363.15 & 1.1021 & 34.41 \\
\hline 358.15 & 1.0970 & 45.47 & - & - & - \\
\hline 363.15 & 1.0941 & 37.62 & - & - & - \\
\hline \multicolumn{3}{|c|}{$\left[\mathrm{C}_{4} \mathrm{C}_{1} \mathrm{Im}\right]\left\{\left[\mathrm{CH}_{3} \mathrm{SO}_{3}\right]_{0.7} \mathrm{Cl}_{0.3}\right\}$} & \multicolumn{3}{|c|}{$\left[\mathrm{C}_{4} \mathrm{C}_{1} \mathrm{Im}\right]\left\{\left[\mathrm{CH}_{3} \mathrm{SO}_{3}\right]_{0.8} \mathrm{Cl}_{0.2}\right\}$} \\
\hline 338.15 & 1.1243 & 82.97 & 343.15 & 1.1297 & 56.84 \\
\hline 343.15 & 1.1215 & 65.89 & 348.15 & 1.1268 & 46.31 \\
\hline 348.15 & 1.1186 & 53.15 & 353.15 & 1.1239 & 38.24 \\
\hline 353.15 & 1.1157 & 43.48 & 358.15 & 1.1209 & 31.96 \\
\hline 358.15 & 1.1128 & 36.03 & 363.15 & 1.1179 & 27.02 \\
\hline
\end{tabular}


363.15

348.15

353.15

Standard uncertainties: $\mathrm{u}(T)=0.02 \mathrm{~K}, \mathrm{u}(P)=1 \mathrm{kPa}$ 0.02 .

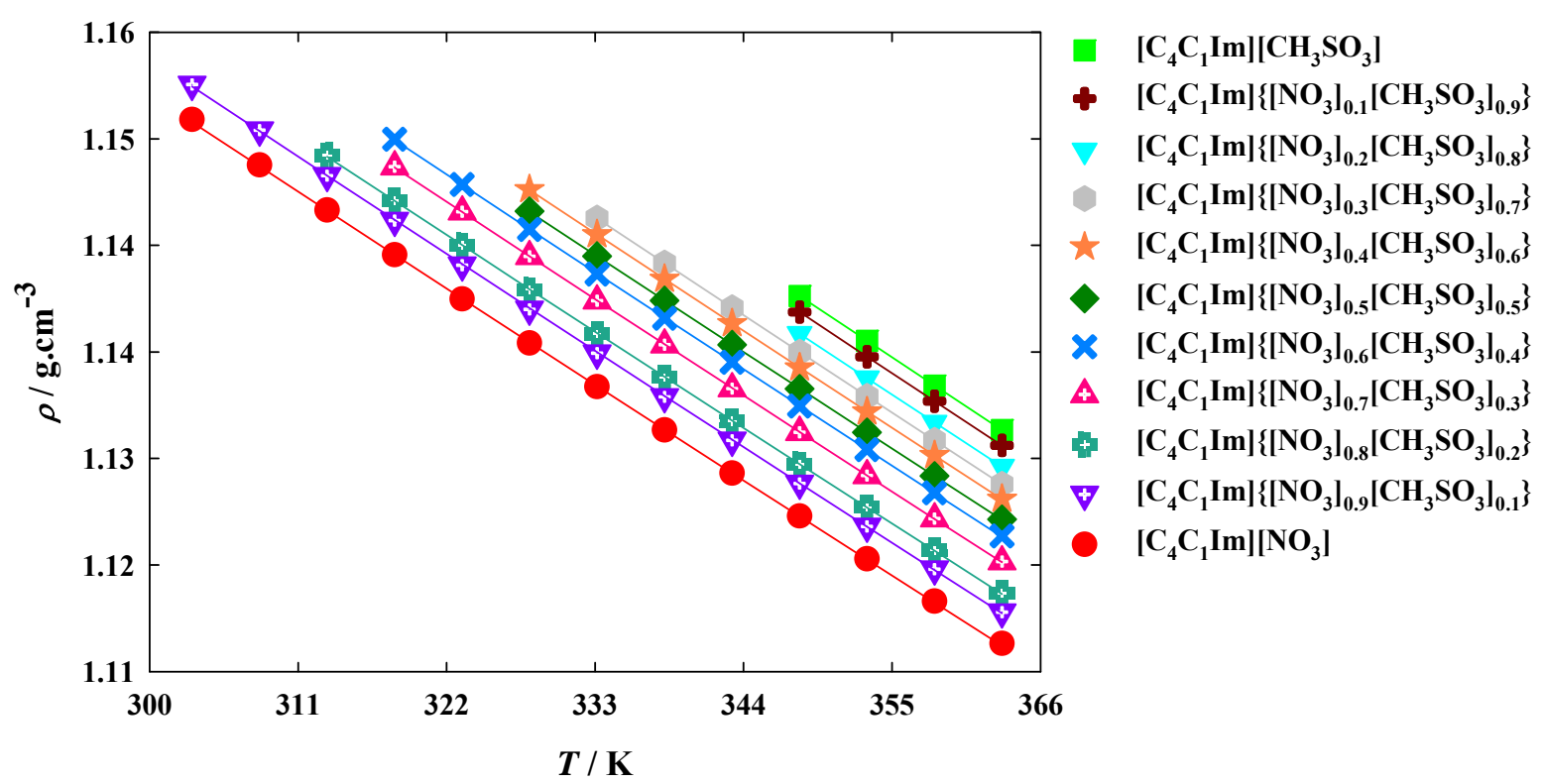

Figure 4. Density and fitted curves for the $\left[\mathrm{C}_{4} \mathrm{C}_{1} \operatorname{Im}\right]\left\{\left[\mathrm{NO}_{3}\right](\mathrm{x})\left[\mathrm{CH}_{3} \mathrm{SO}_{3}\right](1-\mathrm{x})\right\}$ mixtures. Symbols and lines represent experimental points and fitting equations [(1) and (3)], respectively. 


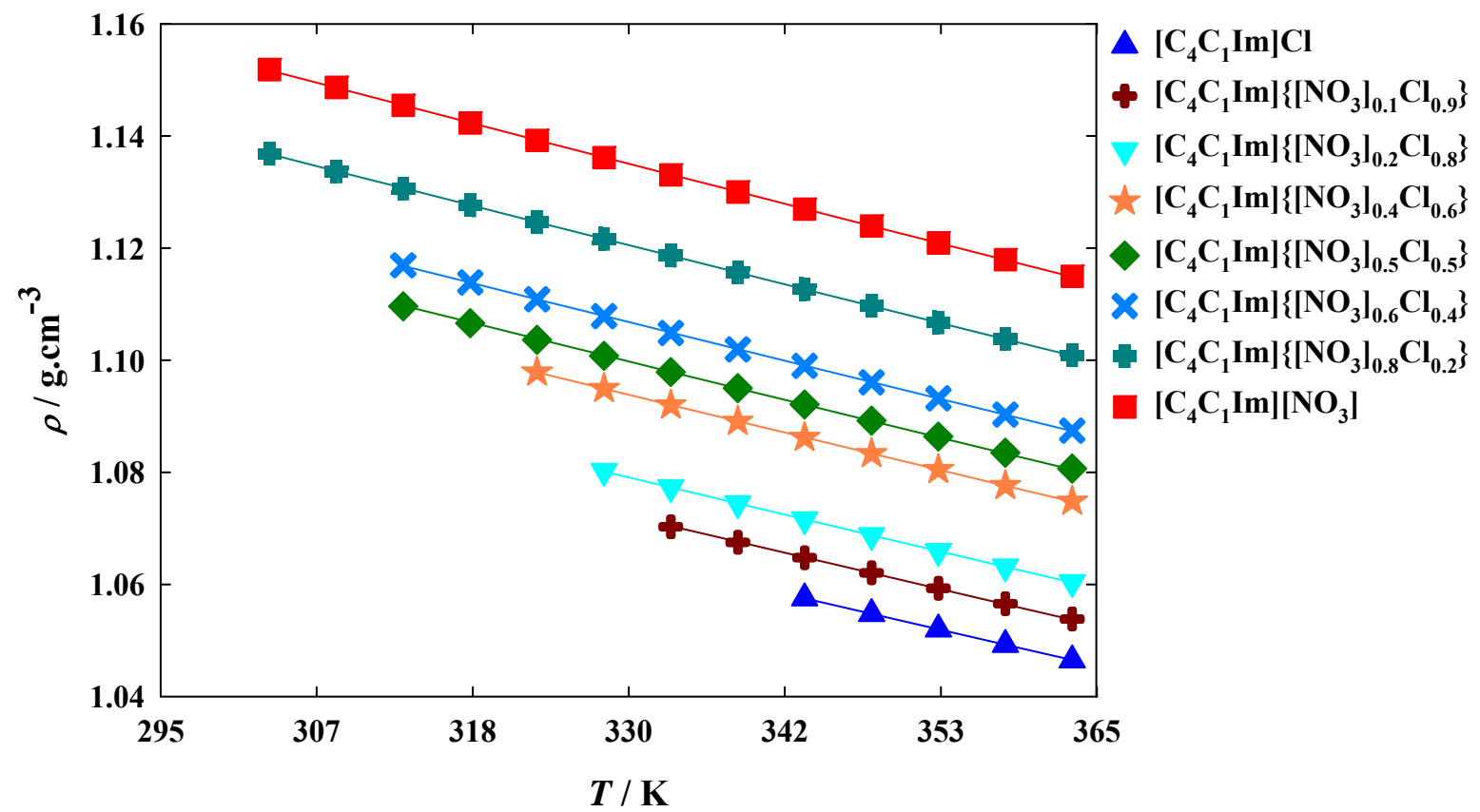

Figure 5. Density and fitted curves for the $\left[\mathrm{C}_{4} \mathrm{C}_{1} \mathrm{Im}\right]\left\{\left[\mathrm{NO}_{3}\right]_{(\mathrm{x})} \mathrm{Cl}_{(1-\mathrm{x})}\right\}$ mixtures. Symbols and lines represent experimental points and fitting equations [(1) and (3)], respectively. 


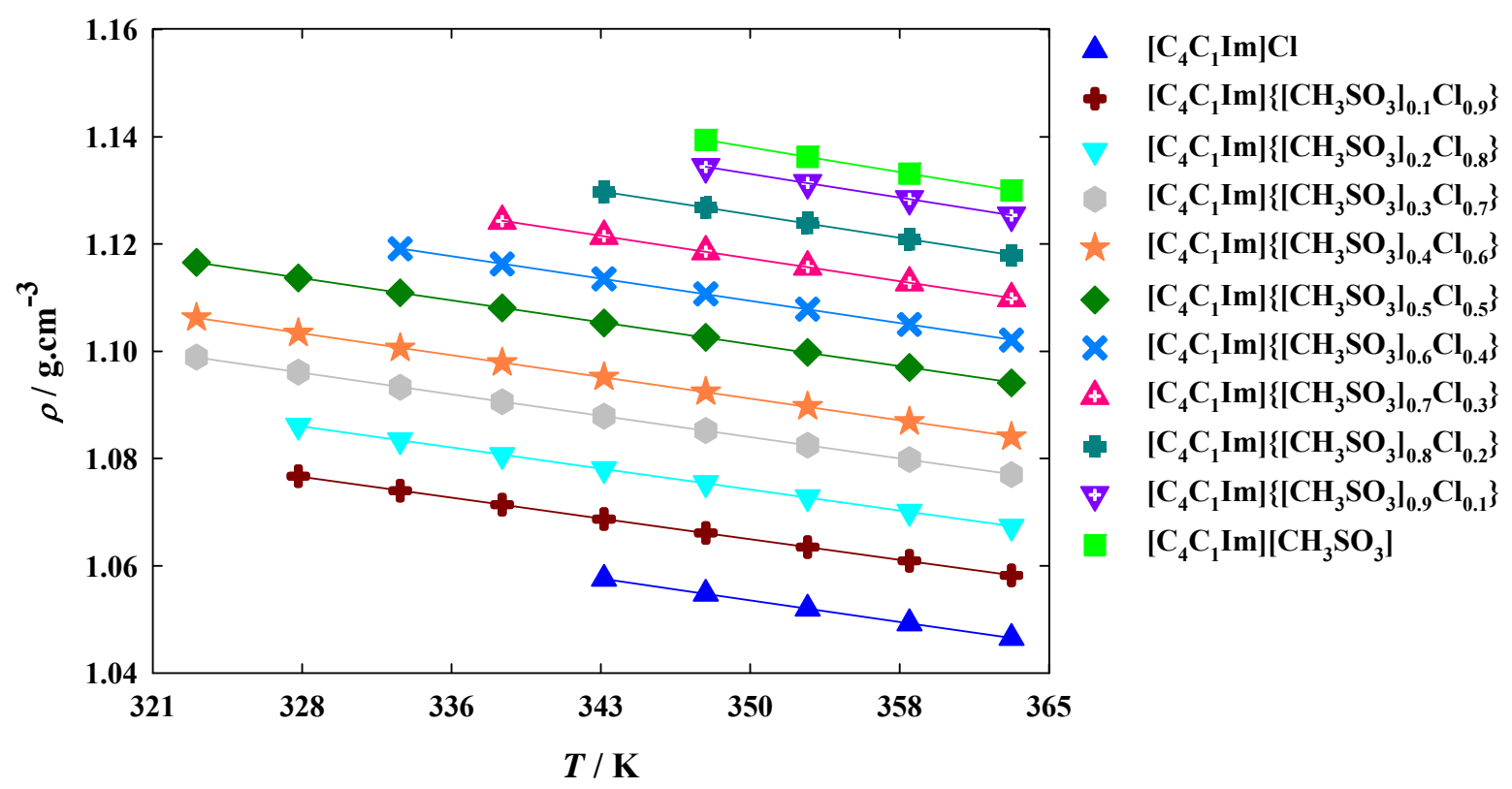

Figure 6. Density and fitted curves for the $\left[\mathrm{C}_{4} \mathrm{C}_{1} \mathrm{Im}\right]\left\{\left[\mathrm{CH}_{3} \mathrm{SO}_{3}\right]_{(\mathrm{x})} \mathrm{Cl}_{(1-\mathrm{-x})}\right\}$ mixtures. Symbols and lines represent experimental points and fitting equations [(1) and (3)], respectively. 


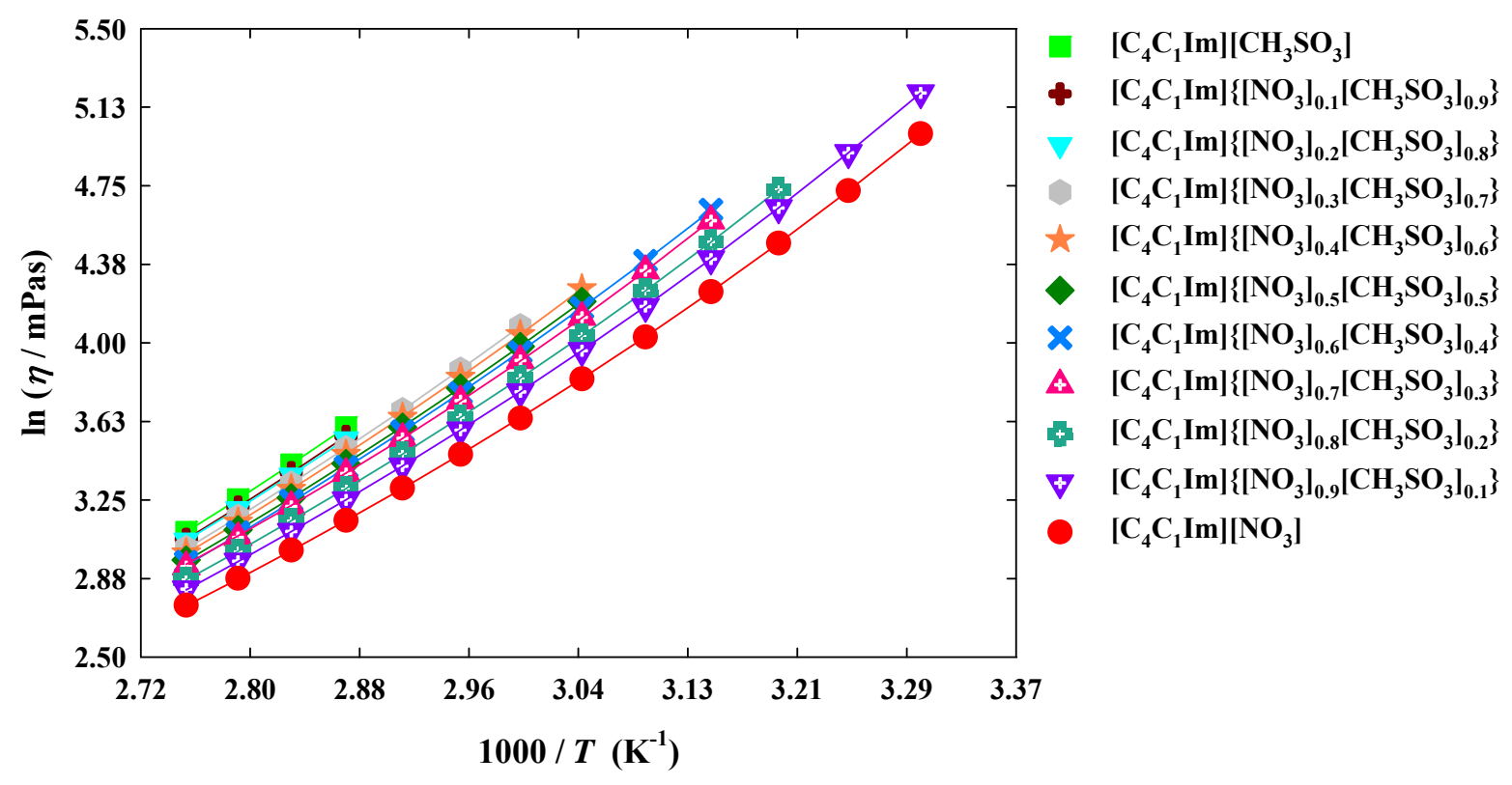

Figure 7. Viscosity and fitted curves as a function of temperature for the $\left[\mathrm{C}_{4} \mathrm{C}_{1} \mathrm{Im}\right]\left\{\left[\mathrm{NO}_{3}\right]_{(\mathrm{x})}\left[\mathrm{CH}_{3} \mathrm{SO}_{3}\right]_{(1-\mathrm{x})}\right\}$ mixtures. Symbols and lines represent experimental points and fitting equations [(1) and (3)], respectively. 


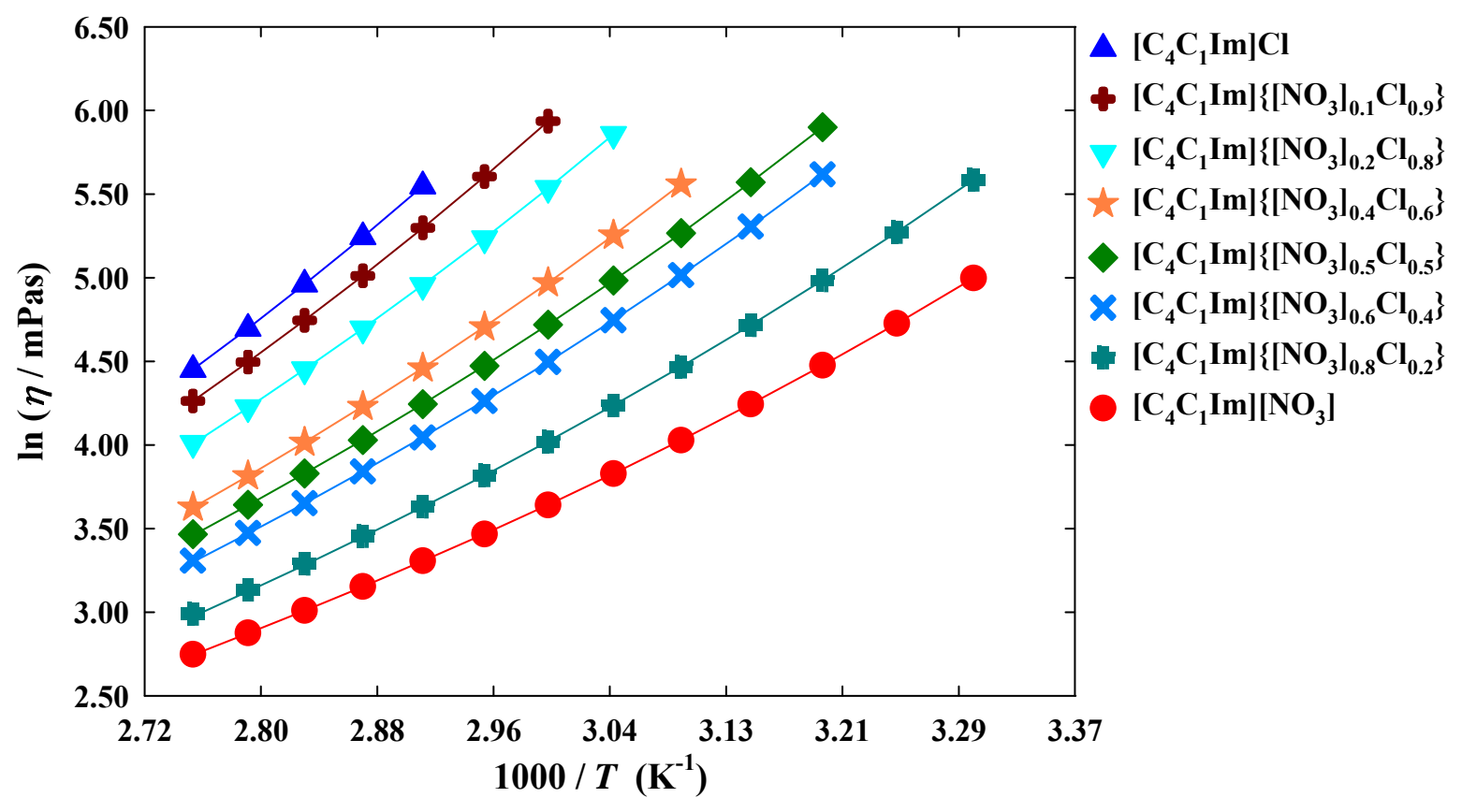

Figure 8. Viscosity and fitted curves as a function of temperature for the $\left[\mathrm{C}_{4} \mathrm{C}_{1} \operatorname{Im}\right]\left\{\left[\mathrm{NO}_{3}\right]_{(\mathrm{x})} \mathrm{Cl}_{(1-}\right.$ x)\} mixture. Symbols and lines represent experimental points and fitting equations [(1) and (3)], respectively. 


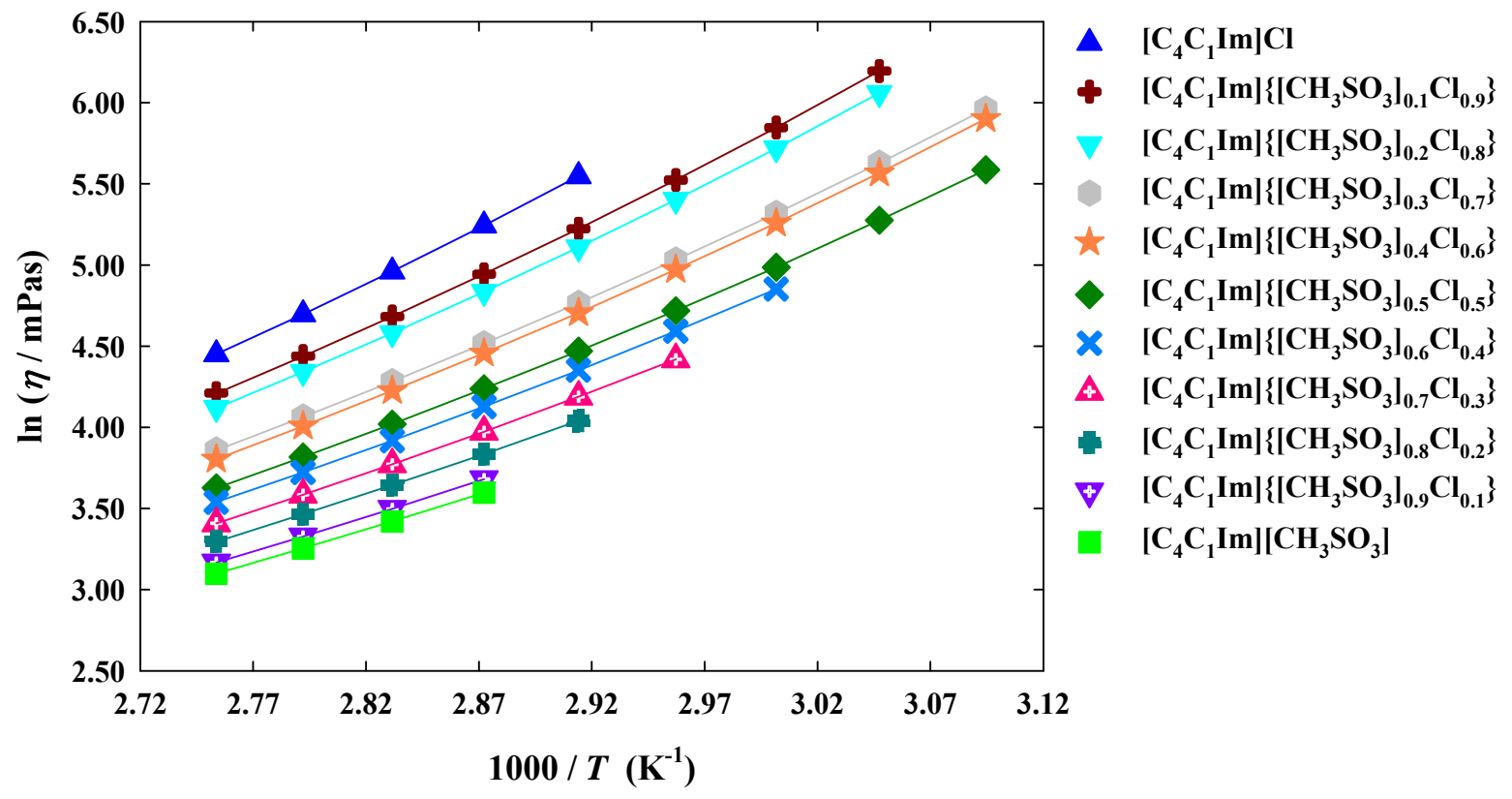

Figure 9. Viscosity and fitted curves as a function of temperature for the $\left[\mathrm{C}_{4} \mathrm{C}_{1} \mathrm{Im}\right]\left\{\left[\mathrm{CH}_{3} \mathrm{SO}_{3}\right]_{(\mathrm{x})} \mathrm{Cl}_{(1-\mathrm{x})}\right\}$ mixture. Symbols and lines represent experimental points and fitting equations [(1) and (3)], respectively. 
Viscosity is a transport property with high relevance in several chemical and industrial procedures, mainly those dependent on pumping, mixing, stirring and mass transfer operations. ${ }^{2,47-}$ ${ }^{49}$ The temperature dependence of this property was performed between 298.15 and $363.15 \mathrm{~K}$ and an Arrhenius-type of fitting for viscosity was performed using the Vogel-Fulcher-Tammann (VFT) equation:

$$
\ln \eta=\ln \eta_{0}+\frac{B}{T-T_{0}}
$$

where $\eta_{0}, B$, and $T_{0}$ are constants. The fitting parameters are summarized in Table S3 of the SI together with the standard deviations which were calculated using equation 2. A comparison between the ideal glass transition, $T_{0}$, calculated from the VFT equation, and the experimental glass transition of pure ILs determined by the DSC experiments is shown in Table 2.

On the other hand, the viscosity of the supercooled liquid $\left[\mathrm{C}_{4} \mathrm{C}_{1} \mathrm{Im}\right]\left[\mathrm{CH}_{3} \mathrm{SO}_{3}\right]$ at $T=323 \mathrm{~K}$ can be estimated using our previous work. ${ }^{34}$ This viscosity of the supercooled liquid should be approximately $100 \mathrm{mPa}$.s. In excellent agreement, the extrapolation of our experimental data down to $T=323 \mathrm{~K}$ gives a value of $\eta=109 \mathrm{mPa} \cdot \mathrm{s}$.

Furthermore, the isobaric thermal expansion coefficient, $\alpha_{\mathrm{p}}$, was also determined for both the pure ILs and their binary mixtures using the following equation:

$$
\alpha_{\mathrm{p}}\left(\mathrm{K}^{-1}\right)=-[\partial \ln \rho / \partial T(\mathrm{~K})]_{\mathrm{p}}
$$

This coefficient is defined as the temperature derivative of $\ln (\rho)$ and their values are illustrated in Figure 10 and listed in Table S7 corresponding to the symmetrical of the $A_{1}$ parameter of equation 1 . The estimated uncertainty of the $\alpha_{\mathrm{p}}$ values is $0.05 \mathrm{~K}^{-1}\left(\mathrm{u}_{\mathrm{r}}\left(\alpha_{\mathrm{p}}\right)=0.05\right)$. The comparison between the estimation of the $\alpha_{\mathrm{p}}$ value for $\left[\mathrm{C}_{4} \mathrm{C}_{1} \mathrm{Im}\right]\left[\mathrm{CH}_{3} \mathrm{SO}_{3}\right]\left(5.4\left(\mathrm{u}_{\mathrm{r}}\left(\alpha_{\mathrm{p}}\right)=0.05 \cdot 10^{-4}\right)\right)$, obtained in a previous work ${ }^{34}$ and the value calculated herein shows an excellent agreement. 


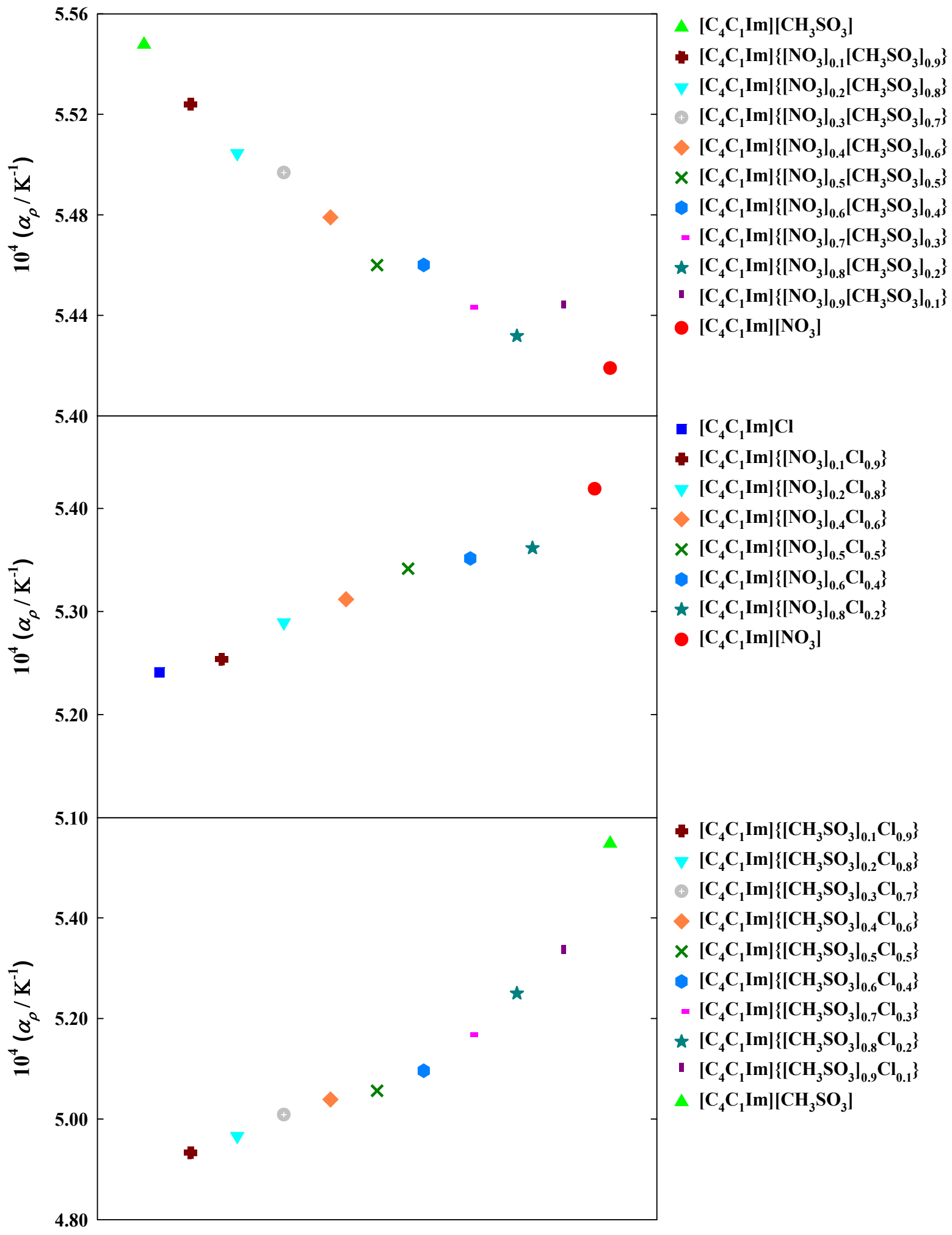

Figure 10. Isobaric thermal expansion coefficients, $\alpha_{\mathrm{p}}$, for the binary systems studied in this work. 
Based on the well-demonstrated ${ }^{50-52}$ notion that the simple sum of the effective molar volumes occupied by the cation and anion precisely determines the IL molar volume, Table 9 displays the calculated effective cation molar volume $\left(V_{\mathrm{c}}^{*}\right)$ and the anions' ones $\left(V_{\mathrm{a}}{ }^{*}\right)$ available in literature and the corresponding estimated molar volume for the pure ILs, $V_{\mathrm{m}}{ }^{*}$, using the following equation:

$$
V_{\mathrm{m}} *(\mathrm{IL})=V_{\mathrm{c}} *+V_{\mathrm{a}}^{*}
$$

Those estimated molar volumes, $V_{\mathrm{m}}$, were compared with the extrapolated molar volumes, $V_{\mathrm{m}}^{\mathrm{ext}}$, obtained in this work and are shown in Table 9, using the estimated densities obtained from the experimental data for the three supercooled ILs at the standard temperature of $T=298.15 \mathrm{~K}$ (and $p=0.1 \mathrm{mPa}$ ). This comparison demonstrates an excellent agreement between estimated $V_{\mathrm{m}}$ * and extrapolated $V_{\mathrm{m}}{ }^{\mathrm{ext}}$ (better than $\left.0.15 \%(0.0015)\right)$.

For the three binary mixtures studied in this work, the excess molar volumes $\left(V^{\mathrm{E}}\right)$ were calculated based on the differences achieved between the molar volume of the final mixture and the molar volume of the hypothetical ideal mixture, as follows:

$$
V^{\mathrm{E}}=V_{\text {mix }}-\left(V_{1} x_{1}+V_{2} x_{2}\right)
$$

where $V_{\text {mix }}$ is the molar volume of the mixture, $V_{1}$ and $V_{2}$ are the molar volume of the two pure ILs, while $x_{1}$ and $x_{2}$ are the corresponding molar fractions. The excess molar volumes versus the molar fraction compositions for all binary mixtures at $T=363.15 \mathrm{~K}$ are shown in Table S8 of SI, and the system composed of $\left[\mathrm{C}_{4} \mathrm{C}_{1} \operatorname{Im}\right]\left\{\left[\mathrm{NO}_{3}\right]_{(x)} \mathrm{Cl}_{(1-x)}\right\}$ is represented in Figure 11. For this binary mixture, the excess molar volumes are positive and the deviations greater than the ones observed for the other mixtures. This behavior indicates that the interactions between the two pure compounds are weaker than the intrinsic interactions of each pure IL. An opposite behavior was 
achieved for the other studied mixtures with negative excess molar volumes. The typical magnitude of the excess molar volumes of ILs binary mixtures is very modest - circa $0.1 \%$ of the overall molar volume. These very small deviations of the mixtures' molar volumes from ideality were already noticed for several mixtures based on an imidazolium-based cation independently of the nature of the anion, in both experimental and theoretical studies..$^{23,26,53}$ 
Table 9. Estimated Molar Volumes and Densities of the Supercooled ILs at $T=298.15 \mathrm{~K}$ (and $p=0.1 \mathrm{mPa})$. $M_{w}$ is the Molar Mass

\begin{tabular}{|c|c|c|c|c|c|c|}
\hline & $\begin{array}{c}\mathrm{M}_{\mathrm{w}} \\
\left(\mathrm{g} \cdot \mathrm{mol}^{-}\right. \\
1)\end{array}$ & $\begin{array}{c}\rho^{\mathrm{ext}} \\
\left(\mathrm{g} \cdot \mathrm{cm}^{-3}\right)\end{array}$ & $\begin{array}{c}V_{\mathrm{m}}^{\mathrm{ext}} \\
\left(\mathrm{cm}^{3} \cdot \mathrm{mol}^{-1}\right)\end{array}$ & $\begin{array}{c}V_{\mathrm{c}}^{*} \\
\left(\mathrm{~cm}^{3} \cdot \mathrm{mol}^{-1}\right)\end{array}$ & $\begin{array}{c}V_{\mathrm{a}}^{*} \\
\left(\mathrm{~cm}^{3} \cdot \mathrm{mol}^{-1}\right)\end{array}$ & $\begin{array}{c}V_{\mathrm{m}}{ }^{*} \\
\left(\mathrm{~cm}^{3} \cdot \mathrm{mol}^{-1}\right)\end{array}$ \\
\hline$\left[\mathrm{C}_{4} \mathrm{C}_{1} \mathrm{Im}\right]\left[\mathrm{NO}_{3}\right]$ & 201.22 & 1.1548 & 174.24 & $133.58^{51}$ & $39.10^{51}$ & 172.68 \\
\hline$\left[\mathrm{C}_{4} \mathrm{C}_{1} \mathrm{Im}\right]\left[\mathrm{CH}_{3} \mathrm{SO}_{3}\right]$ & 234.32 & 1.1715 & 200.02 & $133.58^{51}$ & $66.62^{34}$ & 200.20 \\
\hline$\left[\mathrm{C}_{4} \mathrm{C}_{1} \mathrm{Im}\right] \mathrm{Cl}$ & 174.67 & 1.0828 & 161.32 & $133.58^{51}$ & $25.90^{51}$ & 159.48 \\
\hline
\end{tabular}




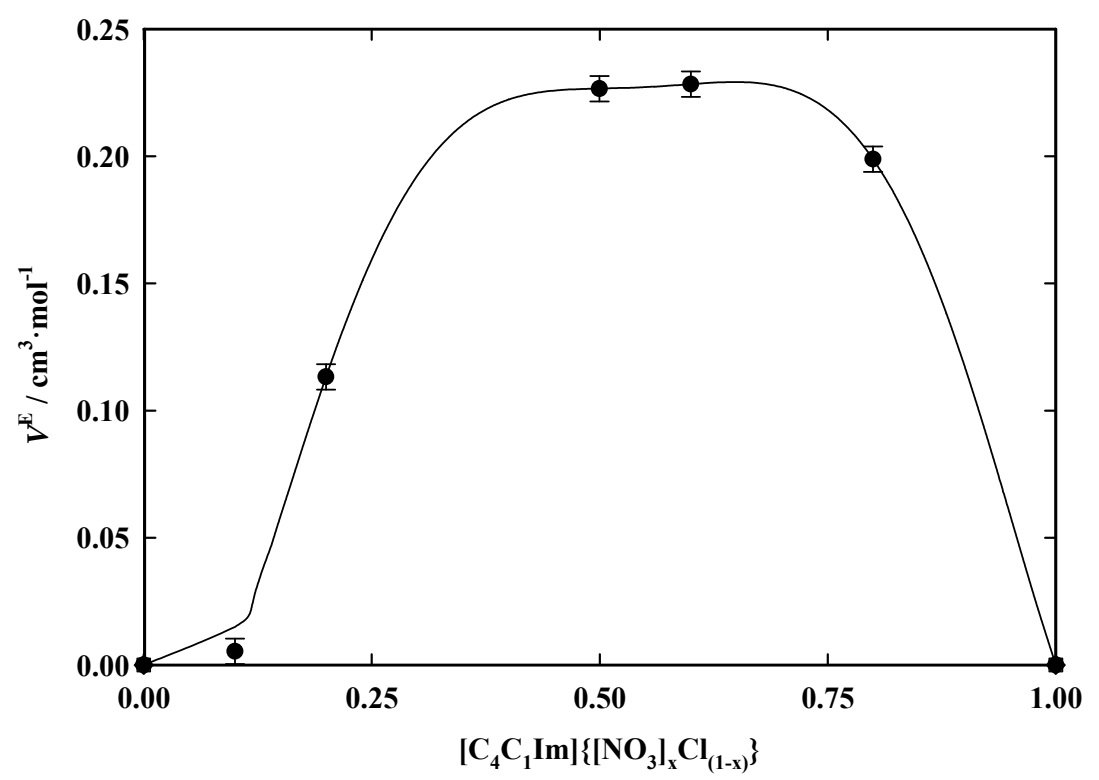

Figure 11. Excess molar volume, $V^{\mathrm{E}}$, for the $\left[\mathrm{C}_{4} \mathrm{C}_{1} \mathrm{Im}\right]\left\{\left[\mathrm{NO}_{3}\right]_{(\mathrm{x})} \mathrm{Cl}_{(1-\mathrm{x})}\right\}$ mixture at $T=363.15 \mathrm{~K}$. The solid line is just a guide to the eye. 
Assuming an ideal viscosity behavior, the difference between the experimental mixture viscosity and the estimated viscosity of the pure compounds must be null. The viscosity deviations from linearity were calculated at $T=363.15 \mathrm{~K}$ from the experimental data applying the following equation:

$\Delta \ln \eta=\ln \eta-\left(x_{1}\right) \ln \eta\left(x_{1}\right)-\left(1-x_{1}\right) \ln \eta\left(1-x_{1}\right)$

where $\eta, \eta_{\left(x_{1}\right)}$, and $\eta_{\left(1-x_{1}\right)}$ are the dynamic viscosity of the mixture, the chemical compound (1) at molar fraction $\left(x_{1}\right)$ and the other chemical compound (2) at molar fraction (1- $\left.x_{1}\right)$, respectively. The obtained results for all the studied binary mixtures are depicted in Table S9 of SI and plotted in Figure 12 for the $\left[\mathrm{C}_{4} \mathrm{C}_{1} \mathrm{Im}\right]\left\{\left[\mathrm{NO}_{3}\right](x) \mathrm{Cl}_{(1-x)}\right\}$ mixture. The viscosity deviations to linearity are negative for both $\left[\mathrm{C}_{4} \mathrm{C}_{1} \operatorname{Im}\right]\left\{\left[\mathrm{NO}_{3}\right]_{(x)} \mathrm{Cl}_{(1-x)}\right\}$ and $\left[\mathrm{C}_{4} \mathrm{C}_{1} \operatorname{Im}\right]\left\{\left[\mathrm{CH}_{3} \mathrm{SO}_{3}\right]_{(x)} \mathrm{Cl}_{(1-x)}\right\}$ mixtures. An opposite behavior is observed for the $\left[\mathrm{C}_{4} \mathrm{C}_{1} \mathrm{Im}\right]\left\{\left[\mathrm{NO}_{3}\right]_{(\mathrm{x})}\left[\mathrm{CH}_{3} \mathrm{SO}_{3}\right]_{(1-\mathrm{x})}\right\}$ mixture where positive deviations were obtained. 


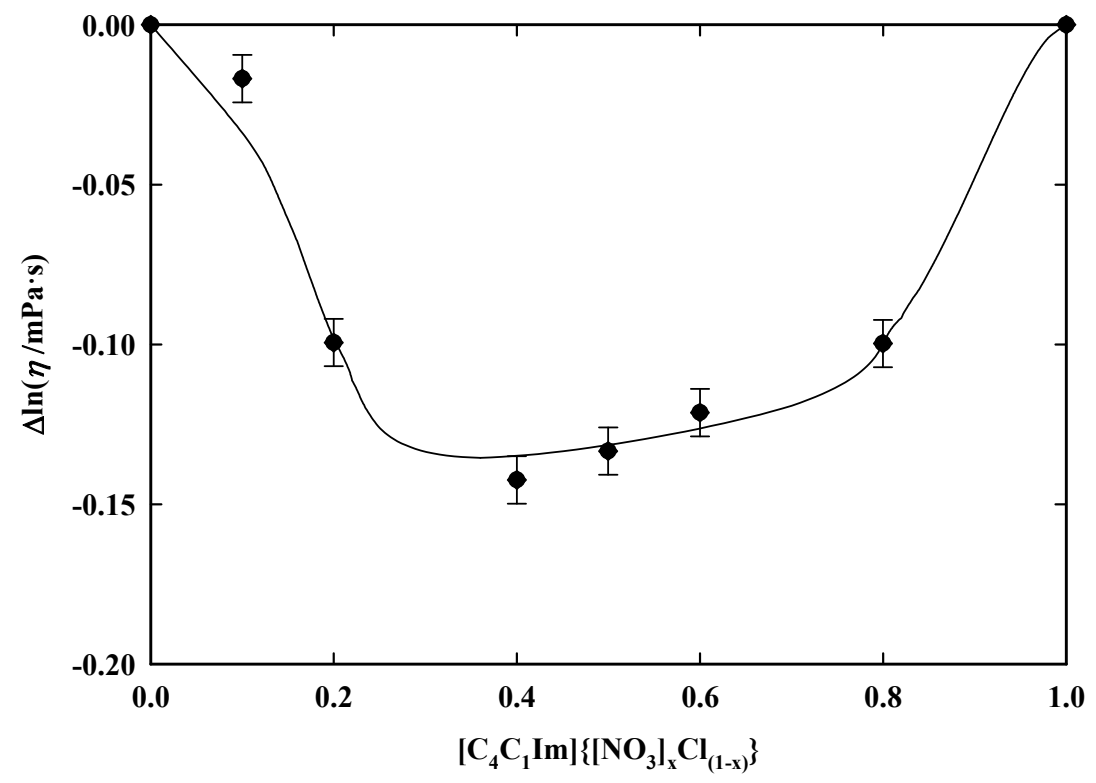

Figure 12. Viscosity deviations to linearity, $\Delta \ln (\eta / \mathrm{mPa} \cdot \mathrm{s})$, for the $\left[\mathrm{C}_{4} \mathrm{C}_{1} \operatorname{Im}\right]\left\{\left[\mathrm{NO}_{3}\right]_{(\mathrm{x})} \mathrm{Cl}_{(1-\mathrm{x})}\right\}$ mixture at $T=363.15 \mathrm{~K}$. The solid line is just a guide to the eye. 


\section{CONCLUSIONS}

This work provides experimentally difficult measurements regarding the properties and the phase behavior of several ILs binary mixtures composed of 1-butyl-3-methylimidazolium and three distinct anions. Most of the work was done at either moderate or high temperatures. Their characterization has included thermal, dynamic and volumetric properties. The three binary mixtures studied in this work revealed quite different solid-liquid equilibria behavior. The systems composed of $\left[\mathrm{C}_{4} \mathrm{C}_{1} \mathrm{Im}\right]\left\{\left[\mathrm{NO}_{3}\right]_{(x)} \mathrm{Cl}_{(1-x)}\right\}$ and $\left[\mathrm{C}_{4} \mathrm{C}_{1} \mathrm{Im}\right]\left\{\left[\mathrm{CH}_{3} \mathrm{SO}_{3}\right]_{(x)} \mathrm{Cl}_{(1-x)}\right\}$ exhibited a usual eutectic behavior with an ideal or quasi-ideal solubility of the compounds in the solid phase, and a eutectic point close to room temperature. In contrast, a continuous solid solution was observed in a broad temperature range for the system constituted of $\left[\mathrm{C}_{4} \mathrm{C}_{1} \mathrm{Im}\right]\left\{\left[\mathrm{NO}_{3}\right]_{(x)}\left[\mathrm{CH}_{3} \mathrm{SO}_{3}\right]_{(1-x)}\right\}$, with a drop on the melting point associated to the addition of $\left[\mathrm{C}_{4} \mathrm{C}_{1} \mathrm{Im}\right]\left[\mathrm{NO}_{3}\right]$. This behavior is associated with a complete miscibility of the binary mixture in the solid phase. Based on the melting and glass temperatures determined for all pure compounds and their binary mixtures, it can be assumed that when these solutions fail to crystallize on cooling, they become a brittle glass at $2 / 3$ of its melting temperature, as estimated by the empirical $2 / 3$ golden rule.

The ideal behavior of these binary mixtures was analyzed based on the excess molar volume and viscosity deviations to linearity. These results demonstrated that the excess molar volumes are positive for $\left[\mathrm{C}_{4} \mathrm{C}_{1} \mathrm{Im}\right]\left\{\left[\mathrm{NO}_{3}\right]_{(x)} \mathrm{Cl}_{(1-x)}\right\}$. This behavior suggests weaker attractive interactions in the mixtures as compared to the intrinsic interactions of each pure IL. A distinct behavior was observed for the other studied mixtures. Regarding the viscosity deviations to linearity for $\left[\mathrm{C}_{4} \mathrm{C}_{1} \mathrm{Im}\right]\left\{\left[\mathrm{NO}_{3}\right]_{(x)} \mathrm{Cl}_{(1-x)}\right\}$ and $\left[\mathrm{C}_{4} \mathrm{C}_{1} \mathrm{Im}\right]\left\{\left[\mathrm{CH}_{3} \mathrm{SO}_{3}\right]_{(x)} \mathrm{Cl}_{(1-x)}\right\}$, higher viscosities were observed for the pure compounds than for the mixtures. 
The opposite behavior was seen for the $\left[\mathrm{C}_{4} \mathrm{C}_{1} \mathrm{Im}\right]\left\{\left[\mathrm{NO}_{3}\right](x)\left[\mathrm{CH}_{3} \mathrm{SO}_{3}\right]_{(1-x)}\right\}$ mixtures, where positive deviations were obtained.

To sum up, the three studied systems showed different behaviors but all very close to an ideal mixture, with small excess properties.

\section{ASSOCIATED CONTENT}

Supporting Information: The Supporting Information is available free of charge on the ACS Publications website. Supplementary tables containing the description of the reagents used, the real molar fraction of each compound used in the binary mixture; density and viscosity of the pure compounds, fitting parameters for density and viscosity, excess molar volume, $V^{\mathrm{E}}$, and viscosity deviations to linearity, $\Delta \ln (\eta / \mathrm{mPa} \cdot \mathrm{s})$, at $T=363.15 \mathrm{~K}$. The ${ }^{1} \mathrm{H}$ NMR spectra of the pure compounds and DSC curves of the pure compounds and binary mixtures are also presented.

\section{AUTHOR INFORMATION}

\section{Corresponding Author}

* Phone: (+351) 212948318; Fax: (+351) 212948550; E-mail: anab@,fct.unl.pt (A.B. Pereiro); luis.rebelo@,fct.unl.pt (L.P.N. Rebelo).

\section{Author Contributions}

The manuscript was written through contributions of all authors. All authors have given approval to the final version of the manuscript.

\section{Funding Sources}


The authors would like to thank the financial support from FCT/MEC (Portugal), through “Investigador FCT 2014” (IF/00190/2014 to A.B.P and IF/00210/2014 to J.M.M.A.), and projects PTDC/EQU-EQU/29737/2017, PTDC/QEQ-FTT/3289/2014, IF/00210/2014/CP1244/CT0003. This work was also supported by the Associate Laboratory for Green Chemistry LAQV (financed by national funds from FCT/MCTES (UID/QUI/50006/2019)) and co-financed by the ERDF under the PT2020 Partnership Agreement (POCI-01-0145-FEDER - 007265). I.V.-F. and N.V.P. thank the industrial advisory board of QUILL for their support.

\section{Notes}

The authors declare no competing financial interest. 


\section{REFERENCES}

(1) Walden, P. Molecular weights and electrical conductivity of several fused salts. Bull. Acad. Imp. Sci. Saint-Pétersbourg 1914, 405-422.

(2) Plechkova, N. V.; Seddon, K. R. Applications of ionic liquids in the chemical industry. Chem. Soc. Rev. 2008, 37, 123-150.

(3) Olivier-Bourbigou, H.; Magna, L. Ionic liquids: perspectives for organic and catalytic reactions. J. Mol. Catalysis 2002, 183, 419-437.

(4) Sato,T.; Masuda G.; Takagi K. Electrochemical properties of novel ionic liquids for electric double layer capacitor applications. Electrochim. Acta 2004, 49, 3603-3611.

(5) MacFarlane, D. R.; Forsyth, M.; Howlett, P. C.; Pringle, J. M.; Sun, J.; Annat, G.; Neil, W.; Izgorodina E. I. Ionic Liquids in Electrochemical Devices and Processes: Managing Interfacial Electrochemistry. Accounts Chem. Res. 2007, 40, 1165-1173.

(6) Armand, M.; Endres, F.; MacFarlane, D. R.; Ohno, H.; Scrosati, B. Ionic-Liquid Materials for the Electrochemical Challenges of the Future. Nat. Mater. 2009, 8, 621-629.

(7) Fedorov, M. V.; Kornyshev, A. A. Ionic Liquids at Electrified Interfaces. Chem. Rev. 2014, $114,2978-3036$.

(8) Rantwijk, F.; Sheldon, R. A. Biocatalysis in Ionic Liquids. Chem. Rev. 2007, 107, 2757-2785.

(9) King, C.; Shamshina, J. L.; Gurau, G.; Berton, P.; Farahnadiah, N.; Khanb, A. F.; Rogers, R. D. A platform for more sustainable chitin films from an ionic liquid process. Green Chem. 2017, 19, 117-126.

(10) Trivedi, T. J.; Srivastava, D. N.; Rogers R. D.; Kumar, A. Agarose processing in protic and mixed protic-aprotic ionic liquids:dissolution, regeneration and high conductivity, high strength ionogels. Green Chem. 2014, 14, 2831-2839. 
(11)Cheng, J.; Shi L.; Lu, J. Amino ionic liquids-modified magnetic core/shell nanocomposite as an efficient adsorbent for dye removal. J. Ind. Eng. Chem. 2016, 36, 206-214.

(12)Petkovic, M.; Ferguson, J. L.; Gunaratne, H. Q. N.; Ferreira, R.; Leitão, M. C.; Seddon, K. R.; Rebelo, L. P. N.; Pereira, C. S. Novel biocompatible cholinium-based ionic liquids-toxicity and biodegradability. Green Chem. 2010, 12, 643-649.

(13)Egorova, K. S.; Ananikov, V. P. Toxicity of ionic liquids: eco (cyto) activity as complicated, but unavoidable parameter for task-specific optimization. ChemSusChem, 2014, 7, 336-360.

(14)Egorova, K. S.; Gordeev, E. G.; Ananikov, V. P. Biological Activity of Ionic Liquids and Their Application in Pharmaceutics and Medicine. Chem. Rev. 2017, 117, 7132-7189.

(15)MacFarlane, D. R.; Seddon, K. R. Ionic Liquids-Progress on the Fundamental Issues. Aust. J. Chem. 2007, 60, 3-5.

(16) Earle, M. J.; Esperança, J. M. S. S.; Gilea, M.; Canongia Lopes, J. N.; Rebelo, L. P. N.; Magee, J. W.; Widegren, J. The distillation and volatility of ionic liquids. Nature 2006, 439, 831-834.

(17) Rogers R. D.; Seddon, K. R. Ionic Liquids - Solvents of the Future? Science 2003, 302, 792794.

(18)Hu, F.Q.; Yuan, H.; Zhang, H.H.; Fang, M. Preparation of solid lipid nanoparticles with clobetasol propionate by a novel solvent diffusion method in aqueous system and physicochemical characterization. Int. J. Pharmaceut. 2002, 239, 121-128.

(19) Sinha, V.R.; Trehan, A. Biodegradable microspheres for protein delivery. J. Control. Release 2003, 90, 261-280.

(20)Ranke, J.; Stolte, S.; Störmann, R.; Arning, J.; Jastorff, B. Design of Sustainable Chemical Products-the Example of Ionic Liquids. Chem. Rev. 2007, 107, 2183-2206. 
(21) Niedermeyer, H.; Hallett, J.P.; Villar-Garcia, I. J.; Hunt, P. A.; Welton, T. Mixtures of ionic liquids. ChemSocRev 2012, 41, 7780-7802.

(22)Chatel, G.; Pereira, J. F. B.; Debbeti, V.; Wang, H.; Rogers, R. D. Mixing ionic liquids “simple mixtures" or "double salts"? Green Chem. 2014, 16, 2051-2083.

(23) Canongia Lopes, J. N.; Cordeiro, T. C.; Esperança, J. M. S. S.; Guedes, H. J. R.; Huq, S.; Rebelo, L. P. N.; Seddon, K. R. Deviations from Ideality in Mixtures of Two Ionic Liquids Containing a Common Ion. J. Phys. Chem. B 2005, 109, 3519-3525.

(24) Torres, M.-J. Ph.D. Thesis, The Queen's University of Belfast, Belfast, 2001

(25)Canongia Lopes, J. N.; Esperança, J. M .S. S.; de Ferro, A. M.; Pereiro, A. B.; Plechkova, N. V.; Rebelo, L. P. N.; Seddon, K. R.; Vázquez-Fernández, I. Protonic Ammonium Nitrate Ionic Liquids and Their Mixtures: Insights into Their Thermophysical Behavior. J. Phys. Chem. B 2016, 120, 2397-2406.

(26) Almeida, H. F. D.; Canongia Lopes, J. N.; Rebelo, L. P. N.; Coutinho, J. A. P.; Freire, M. G.; Marrucho, I. M. Densities and Viscosities of Mixtures of Two Ionic Liquids Containing a Common Cation. J. Chem. Eng. Data 2016, 61, 2828-2843.

(27) Pereiro, A. B.; Araújo, J. M. M.; Oliveira, F. S.; Bernardes, C. E. S.; Esperança, J. M. S. S.; Canongia Lopes, J. N.; Marrucho, I. M.; Rebelo, L. P. N. Inorganic salts in purely ionic liquid media: the development of high ionicity ionic liquids (HIILs). Chem. Comm. 2012, 48, 36563658.

(28) Arce A.; Earle, M. J.; Katdare, S. P.; Rodríguez H.; Seddon, K. R. Mutually immiscible ionic liquids. Chem. Commun. 2006, 2548-2550.

(29) Seddon K. R.; Stark, A.; Torres, M.-J. Influence of chloride, water, and organic solvents on the physical properties of ionic liquids. Pure Appl. Chem. 2000, 72, 2275-2287. 
(30) Ferguson, J. L.; Holbrey, J. D.; Ng, S.; Plechkova, N. V.; Seddon, K. R.; Tomaszowska, A. A.; Wassell, D. F. A greener, halide-free approach to ionic liquid synthesis. Pure App. Chem. 2012, 84, 723-744.

(31) Stolarska, O.; Soto, A.; Rodríguez, H.; Smiglak, M. Properties modification by eutectic formation in mixtures of ionic liquids. RSC Adv. 2015, 5, 22178-22187.

(32) Strechan, A. A.; Kabo, A. G.; Paulechka, Y. U.; Blokhin, A. V.; Kabo, G. J.; Shaplov, A. S.; Lozinskaya, E. I. Thermochemical properties of 1-butyl-3-methylimidazolium nitrate. Thermochim. Acta 2008, 474, 25-31.

(33) Cassol, C. C.; Ebeling, G.; Ferrera, B.; Dupont, J. A simple and practical method for the preparation and purity determination of halide-free imidazolium ionic liquids. Adv. Synth. Catal. 2006, 348, 243-248.

(34) Blesic, M.; Swadźba-Kwaśny, M.; Belhocine, T.; Gunaratne, H. Q. N.; Lopes, J. N. C.; Gomes, M. F. C.; Pádua, A. A. H.; Seddon, K. R.; Rebelo, L. P. N. 1-Alkyl-3methylimidazolium alkanesulfonate ionic liquids, $\left[\mathrm{CH}_{2+1} \mathrm{mim}\right]\left[\mathrm{CH}_{2+1} \mathrm{SO}_{3}\right]$ : synthesis and physicochemical properties. Phys. Chem. Chem. Phys. 2009, 11, 8939-8948.

(35) Nemoto, F.; Kofu, M.; Yamamuro O. Thermal and Structural Studies of ImidazoliumBased Ionic Liquids with and without Liquid-Crystalline Phases: The Origin of Nanostructure. J. Phys. Chem. B 2015, 119, 5028-5034.

(36) Yamamuro O.; Minamimoto Y.; Inamura Y.; Hayashi S.; Hamaguchi H.-o. Heat capacity and glass transition of an ionic liquid 1-butyl-3-methylimidazolium chloride. Chem. Phys. Lett. 2006, 423, 371-375.

(37) Griffith, E. J. Phase Transitions of the Ammonium Nitrate-Magnesium Nitrate System. . $J$. Chem. Eng. Data, 1963, 8, 22-25. 
(38) Kabo, A.G.; Diky, V.V. Details of calibration of a scanning calorimeter of the triple heat bridgetype. Thermochim. Acta 2000, 347, 79-84.

(39) Shamsuzzoha M.; Lucas, B. W. Polymorphs of rubidium nitrate and their crystallographic relationships. Can. J. Chem. 1988, 66, 819-823.

(40) Kleppa, O. J.; McCarty, F. G. Heats of Fusion of the Monovalent Nitrates by HighTemperature Reaction Calorimetry. J. Chem. Eng. Data, 1963, 8, 331-332.

(41) Saha, S.; Hayashi, S.; Kobayashi, A.; Hamaguchi, H. Crystal structure of 1-butyl-3methylimidazolium chloride. A clue to the elucidation of the ionic liquid structure. Chem. Lett. 2003, 32, 740-741.

(42) Abe, H.; Takekiyo, T.; Yoshimura, Y.; Saihara, K.; Shimizu, A. Anomalous Freezing of Nano-Confined Water in Room-Temperature Ionic Liquid 1-Butyl-3-Methylimidazolium Nitrate. Chem. Phys. Chem. 2016, 17, 1136-1142.

(43) Teles, A. R. R.; Correia, H.; Maximo, G. J.; Rebelo, L. P. N.; Freire, M. G.; Pereiro, A. B.; Coutinho, J. A. P. Solid-liquid equilibria of binary mixtures of fluorinated ionic liquids. Phys. Chem. Chem. Phys. 2016, 18, 25741-25750.

(44) Maximo, G. J.; Santos, R. J. B. N.; Brandão, P.; Esperança, J. M. S. S.; Costa, M. C.; Meirelles, A. J. A.; Freire, M. G.; Coutinho, J. A. P. Generating Ionic Liquids from Ionic Solids: An Investigation of theMelting Behavior of Binary Mixtures of Ionic Liquids. Cryst. Growth Des. 2014, 14, 4270-4277.

(45) Kapko,V.; Matyushov, D. V.; Angel, C. A. Potential-tuning molecular dynamics studies of fusion, and the question of ideal glassformers: (I) The Gay-Berne model. arXiv:1011.2810 2011, Cornell University. 
(46) Belieres, J.; Angell, C. A. Protic Ionic Liquids: Preparation, Characterization, and Proton Free Energy Level Representation. J. Phys. Chem. B 2007, 111, 4926-4937.

(47) Aparicio, S.; Atilhan, M.; Karadas, F. Thermophysical properties of pure ionic liquids: review of present situation. Ind. Chem. Res. 2010, 49, 9580-9595.

(48) França, J. M. P.; Castro, C. A. N.; Lopes, M. M.; Nunes, V. M. B. Influence of thermophysical properties of ionic liquids in chemical process design. J. Chem. Eng. Data, 2009, 54, 2569-2575.

(49) Pereiro, A. B.; Araújo, J. M. M.; Martinho, S.; Alves, F.; Nunes, S.; Matias, A.; Duarte, C. M. M.; Rebelo, L. P. N.; Marrucho, I. M. Fluorinated ionic liquids: properties and applications. ACS Sustain. Chem. Eng. 2013, 1, 427-439.

(50) Esperança, J. M. S. S.; Guedes, H. J. R.; Blesic, M.; Rebelo, L. P. N. Densities and Derived Thermodynamic Properties of Ionic Liquids. 3. Phosphonium-Based Ionic Liquids over an Extended Pressure Range. J. Chem. Eng. Data 2006, 51, 237-242.

(51) Rebelo, L. P. N.; Lopes, J. N. C.; Esperança, J. M. S. S.; Guedes, H. J. R.; Łachwa, J.; Najdanovic-Visak, V.; Visak, Z. P. Accounting for the Unique, Doubly Dual Nature of Ionic Liquids from a Molecular Thermodynamic and Modeling Standpoint. Acc. Chem. Res. 2007, $40,1114-1121$.

(52) Rebelo, L. P. N.; Najdanovic-Visak, V.; de Azevedo, R. G.; Esperança, J. M. S. S.; da Ponte, M. N.; Guedes, H. J. R.; Visak, Z. P.; de Sousa, H. C.; Szydlowski, J.; Lopes, J. N. C.; Cordeiro, T. C. Phase Behavior and Thermodynamic Properties of Ionic Liquids, Ionic Liquid Mixtures, and Ionic Liquid Solutions, in Ionic Liquids III A: Fundamentals, Progress, Challenges, and Opportunities, ACS Symposium Series 2005, 901, 270-291. 
(53) Brüssel, M.; Brehm, M.; Pensado, A. S.; Malberg, F.; Ramzan, M.; Stark A.; Kirchner, B. On the ideality of binary mixtures of ionic liquids. Phys. Chem. Chem. Phys. 2012, 14, 1320413215. 